San Jose State University

SJSU ScholarWorks

Master's Theses

Master's Theses and Graduate Research

Spring 2013

\title{
Ecotourism as a Tool for Conservation of Coast Redwoods in Santa Cruz County, California
}

Chandana Rao

San Jose State University

Follow this and additional works at: https://scholarworks.sjsu.edu/etd_theses

\section{Recommended Citation}

Rao, Chandana, "Ecotourism as a Tool for Conservation of Coast Redwoods in Santa Cruz County, California" (2013). Master's Theses. 4308.

DOI: https://doi.org/10.31979/etd.wxc4-g4sb

https://scholarworks.sjsu.edu/etd_theses/4308

This Thesis is brought to you for free and open access by the Master's Theses and Graduate Research at SJSU ScholarWorks. It has been accepted for inclusion in Master's Theses by an authorized administrator of SJSU ScholarWorks. For more information, please contact scholarworks@sjsu.edu. 


\title{
ECOTOURISM AS A TOOL FOR CONSERVATION OF COAST REDWOODS IN SANTA CRUZ, CALIFORNIA
}

\author{
A Thesis \\ Presented to \\ The Faculty of the Department of Environmental Studies \\ San José State University
}

In Partial Fulfillment

of the Requirements for the Degree

Master of Science

by

Chandana Rao

May 2013 
(C) 2013

Chandana Rao

\section{ALL RIGHTS RESERVED}


The Designated Thesis Committee Approves the Thesis Titled

ECOTOURISM AS A TOOL FOR CONSERVATION OF COAST REDWOODS IN SANTA CRUZ, CALIFORNIA

by

Chandana Rao

APPROVED FOR THE DEPARTMENT OF ENVIRONMENTAL STUDIES

SAN JOSÉ STATE UNIVERSITY

May 2013

Dr. Will Russell

Environmental Studies Department

Dr. Natalie Boero

Department of Sociology

Mr. Alan Leventhal

Department of Anthropology 


\section{ABSTRACT \\ ECOTOURISM AS A TOOL FOR CONSERVATION OF \\ COAST REDWOODS IN SANTA CRUZ, CALIFORNIA}

\section{By Chandana Rao}

According to the World Tourism Organization, ecotourism is the fastest growing segment of the tourism industry, generating $\$ 300$ billion in annual revenue. Ecotourism aims to control the damaging effects of conventional mass tourism and tries to overcome tourism's environmental and socio-cultural challenges. In an ideal situation, ecotourism can help conserve fragile biodiversity, build ties between parks and communities, and increase awareness of environmental issues; it also includes a profit impetus for businesses.

This research was conducted to evaluate the potential for developing ecotourism as a conservation tool in the four redwoods state parks of Santa Cruz County. The study assessed the tangible and intangible values of coast redwood forests, as well as management policies of California State Parks. The study used a multi-method approach to gather qualitative and quantitative data from tourists and state park officials. Results indicated that, while a foundation for ecotourism existed within the state park framework, there was a disparity in management policies and their implementation, and improvements in tourist education were required. These findings lent support to the idea of true and conservation-oriented ecotourism as well as appropriate management for endangered coast redwood forests. 


\section{ACKNOWLEDGEMENTS}

I would like to acknowledge and thank my mother for her patience, constant encouragement and for never letting me give up. Thanks for sticking by me! To Chimmi, thank you for providing your "medicine" and laughter when I really needed it. To my wonderful friends, Diana, Vijaya, and Supriya, who were my sounding boards as I droned on about my thesis, thank you! I promise I'll be there when you do your thesis.

My deepest gratitude to the California State Parks staff and docents who took valuable time to patiently answer my questions, queries well after my scheduled time. Special thanks must go to Mark Hylkema, Susan Blake and Linda Hitchcock without whom this thesis would not have been successful.

My ever supportive committee deserves a big thank you. Dr. Russell, Alan and Dr. Boero, thank you for encouraging me, sitting with me and going through the drafts.

My warmest regards and thanks to Alan Leventhal and Prof. Priya Raman, who helped me figure out the quantitative aspect of my thesis. 


\section{TABLE OF CONTENTS}

List of Figures....................................................................................................................................... vii

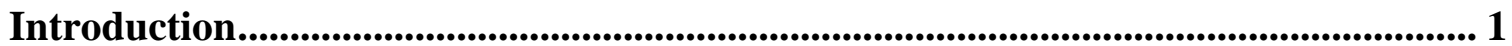

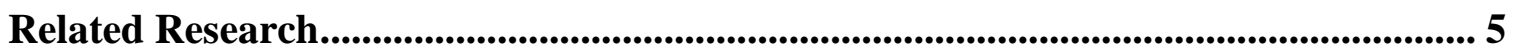

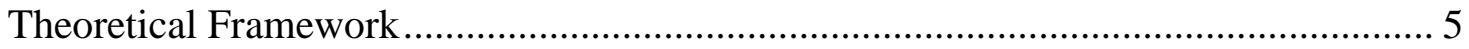

Comprehensive and Minimalist Ecotourism as Ideal Types .................................... 9

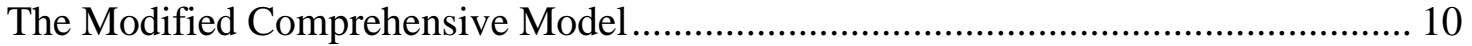

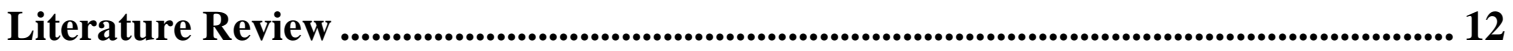

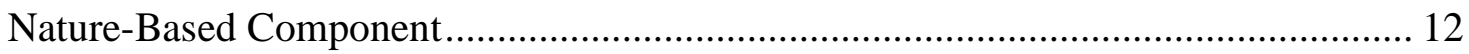

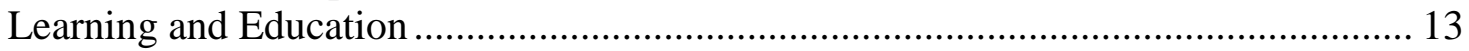

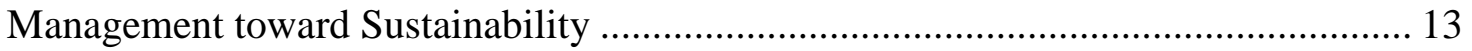

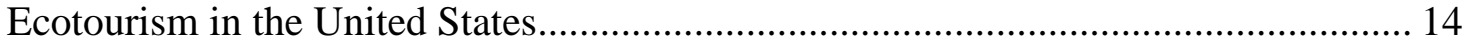

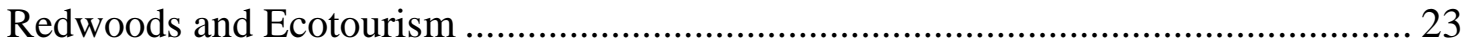

The Significance of Charismatic Flagship Species................................................. 25

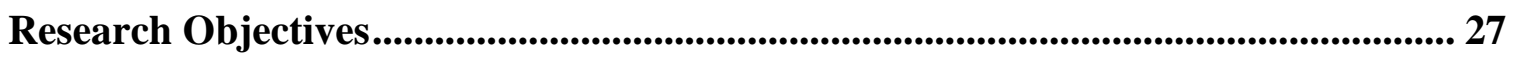

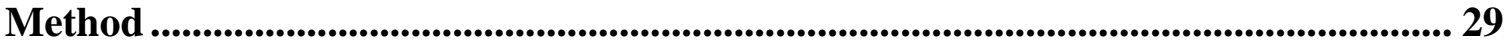

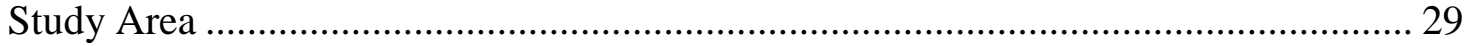

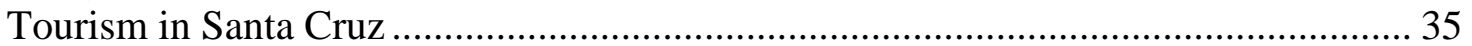

Status of California State Parks ............................................................................. 36

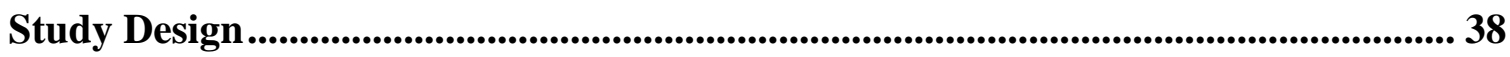

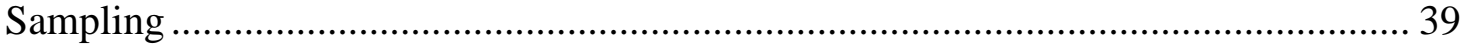

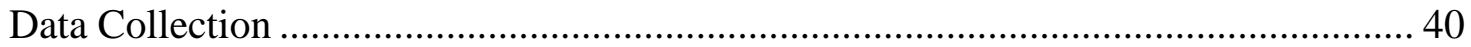

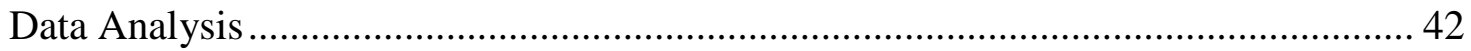

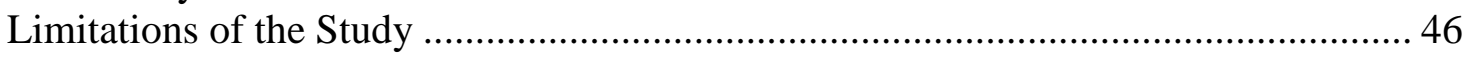

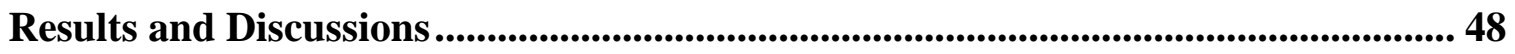

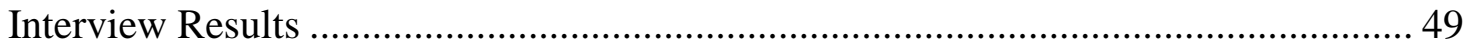

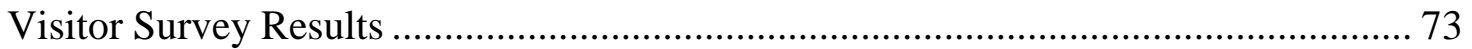

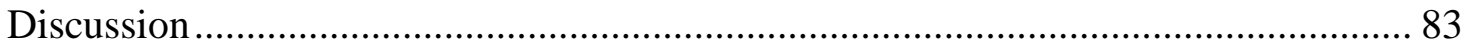

Nature-Based Component..................................................................................... 84

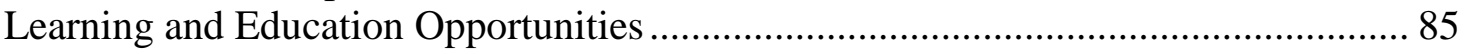

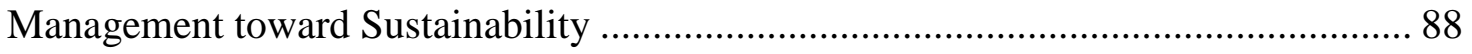

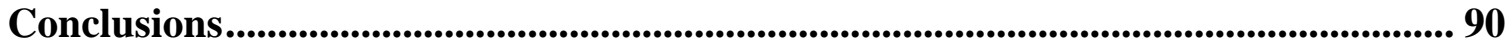

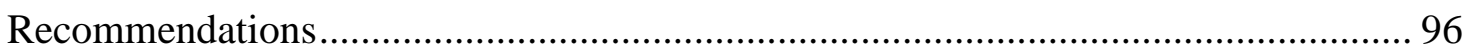

References .................................................................................................................... 97

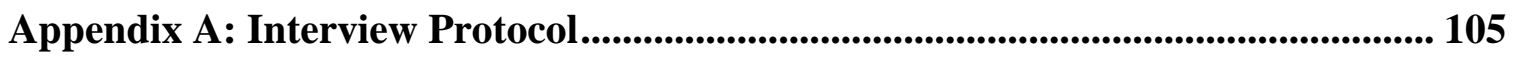

Appendix B: Survey Questions................................................................................... 107 


\section{List of Figures}

Figure 1. The ecotourism paradigm............................................ 7

Figure 2. The ecotourism paradigm in a management context..................... 8

Figure 3. Comprehensive minimalist model................................... 9

Figure 4. Modified comprehensive model................................... 11

Figure 5. Location of Santa Cruz County redwood parks........................ 30

Figure 6. The qualitative research process......................................45

Figure 7. Age distribution.............................................. 75

Figure 8. Origin of tourists................................................. 75

Figure 9. Frequency of tourist visits to redwood forests........................ 76

Figure 10. Tourist motivations to visit a redwood forest.......................... 77

Figure 11. Awareness of risks to redwood forests.............................. 79

Figure 12. Willingness to pay to enter a redwood state park $\ldots \ldots \ldots \ldots \ldots \ldots \ldots \ldots \ldots \ldots$

Figure 13. Willingness to pay towards the conservation of redwood forests............ 81

Figure 14. Tourist expectations in a redwood park..............................82 


\section{Introduction}

Tourism is the world's largest industry (Giannecchini, 2002; Goodwin, 1996; Pretes, 1995), and ecotourism is its fastest growing and most debated sector. The term ecotourism was first used by Romeril (1985) as a form of tourism combining increasingly destructive mass tourism and conservation. Ecotourism is mostly associated with developing countries, where an element of the exotic is expected by the tourists who are usually from developed countries. Tourism has made inroads into numerous spaces in the world, diversifying into all types of ecosystems. A century into the modern era of travel and tourism, few precious corners of the planet remain truly off the beaten path today. Decades of tourism have exposed the fact that this industry can often leave behind considerable environmental and socio-cultural impacts at the destinations. The approach

of ecotourism is aimed at reducing or eliminating these impacts by providing an alternate form of tourism that strives to have positive socio-cultural and environmental goals.

There is a debate among scholars as to the appropriate definition of ecotourism, and there is no true consensus. However, it is generally agreed that ecotourism involves travel to areas of natural beauty in relatively undeveloped areas where activities are sustainable and there is equitable distribution of economic benefits to the local residents (Ziffer, 1989). One of the earliest accepted definitions of ecotourism was given by Ceballos-Lascurain (1987) as:

Ecotourism is tourism that involves travelling to relatively undisturbed or uncontaminated natural areas with the specific objective of admiring, 
studying, and enjoying the scenery and its wild plants and animals, as well as any cultural features (both past and present) found in the areas (p. 14).

A more widely accepted version was given by Ziffer (1989):

Ecotourism: a form of tourism inspired primarily by the natural history of an area, including its indigenous cultures. The ecotourist visits relatively undeveloped areas in the spirit of appreciation, participation and sensitivity. The ecotourist practices a non-consumptive use of wildlife and natural resources and contributes to the visited area through labor or financial means aimed at directly benefiting the conservation of the site and the economic wellbeing of the local residents (p. 99).

The degree of ecotourism may vary with activities of, and impacts by, the tourist. Many authors contend that ecotourism is not just travel to natural areas (Aylward and Freedman, 1992; Lindberg, 1991).

Bjork (2000) notes:

Ecotourism is not farm tourism, nature tourism or adventure tourism, but a unique tourism form that has become very popular due to the greening of markets, increasing knowledge of the fragility of the environment, better informed managers, and the recognition that there is a close relationship between good ecology and good economy (p. 23). 
Most ecotourism projects are introduced in areas with unusual ecological features and stunning views of flora and fauna. A major threat to the loss of biodiversity across the world is human impact in the forms of unsustainable and destructive tourism, timber harvesting, pollution, widespread agricultural practices, and deforestation (Lindberg \& Sproule, 1996). The rain forests of the world are prime examples of a destructive combination of ecotourism and timber extraction, but other types of forests are also impacted heavily depending on the potential commercial value of the resources extracted. Ecotourism, as an activity, has also impacted marine communities of the world by destroying fragile corals and disturbing behaviors of marine creatures such as dolphins and whales. In Belize, excessive ecotourism has led to polluted ocean waters; ecotourism in the Himalayas has increased trash on trails; beaches in many parts of the developing world have seen an increase in plastic waste and debris (Goodwin, 1996; King \& Stewart, 1996).

In the 1990s, the idea of promoting pure nature-based tourism, one that ensured socio-economic, cultural, and environmental advantages, became popular (Wearing \& Neil, 1999). This interest was partly fostered by the term sustainability, which was a buzzword taken to mean development with minimal negative impacts (Kruger, 2005). While the development of tourist resorts and projects began all over unexplored and less explored regions of the world, there was no real solution on how to curtail the negative impacts. In addition, the developers of these projects were enticed by the relatively fast revenue generation of ecotourism activities. Due to the need for fast returns on investment, ecotourism became a vehicle for conservation, especially in developing 
countries. Apart from revenue, ecotourism generated much needed foreign exchange, both at the local and domestic levels.

In spite of the mentioned obstacles, ecotourism is a sector of the tourism industry that is gaining popularity across the world. To ensure greater sustainability, precise and careful planning is required during all stages of project development and implementation. 


\section{Related Research}

\section{Theoretical Framework}

The broad theoretical framework used for this study is that of sustainable development. According to the Brundtland Commission of 1983, sustainable development is the use of resources in a way that does not compromise the ability of future generations to meet their needs. With exploding populations and an unprecedented pressure on natural ecosystems, there are factions of people who prioritize ecosystem conservation over development, and other factions who favor development over conservation. Michaelidou, Decker, and Lassoie (2002) theorize that ecosystem conservation and community survival are interdependent and thus, equally important.

For any form of ecotourism development to succeed in the long term, environmental sustainability and protection is the focal point for both the tourists and tourism promoters. Cater (1997) theorizes that protecting the environment benefits all the stakeholders in the tourism paradigm. The relationship with the environment is a symbiotic one for the stakeholders. Conserving the natural attractions that brought tourists to the area in the first place has an ethical and economic justification. If the environment is protected and sustained, an increase in tourist satisfaction and revenue generation can be expected. Environmental protection is the center of all direct benefits from tourism, such as improved standards of living for local populations, profits for tourist service developers, and sustained visitor attractions. The relationship is a mutually beneficial one, as 
increased conservation leads to increased returns in terms of tourist visitation, increased revenue and profits.

Visitors can also play a role in protecting the natural attractions so that they can preserve the attractions for future generations. In successful ecotourism, the relationship between people, resources, and tourism are such that positive contributions to each other are symbiotic processes. The Ecotourism Paradigm (Ross \& Wall, 1999) explains these interactions. For each of the factors (communities, natural resources, and tourism) to gain positively, their contribution to the other two factors must be positive (Figure 1). It should not be assumed that a symbiotic and mutually acceptable relationship will ensue automatically between these three facets. In successful cases, this synergistic relationship is facilitated by appropriate management. With fragile biodiversity, management may have a significantly difficult task in combining these three facets. In many cases, people dependent on resources in fringe areas of ecotourism projects may object to strict regulations and prohibitions on use of natural amenities in the area (Mackinnon, Mackinnon, Child, \& Thorsell, 1986). 


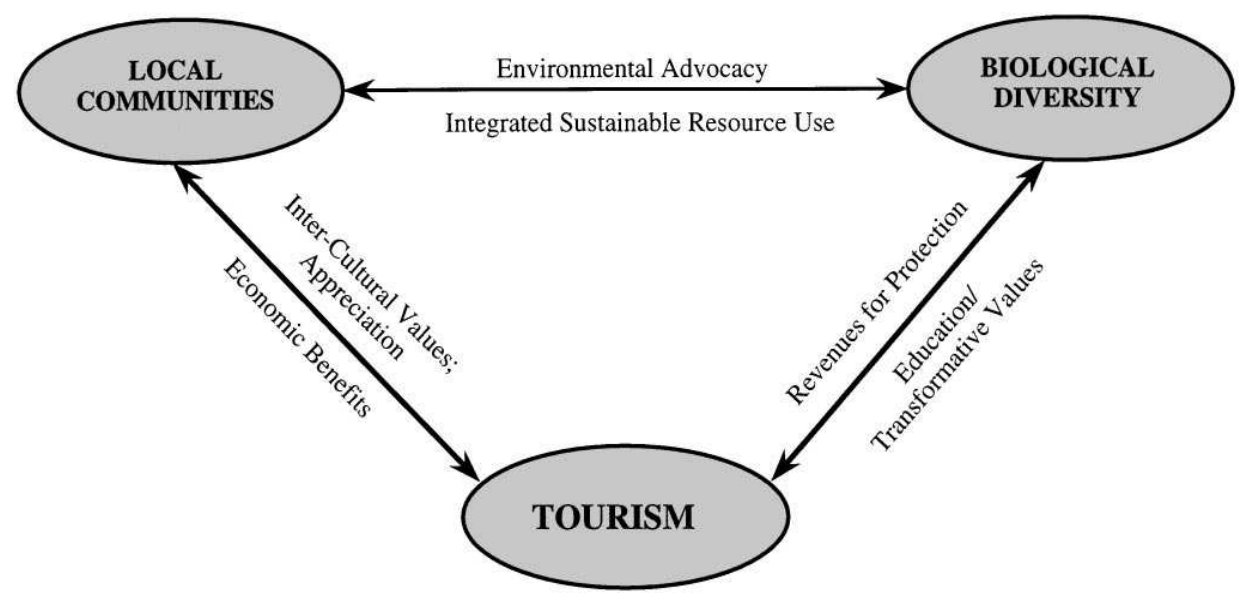

Figure 1. The Ecotourism Paradigm describes the relationships between external stakeholders, but without the symbiotic and central management policies. From "Ecotourism: Towards Congruence between Theory and Practice", by S. Ross and G. Wall, 1999, Tourism Management, 20(1), p. 126. Copyright 1999 by Elsevier. Adapted with permission.

Without proper management, it is unlikely that ecotourism will be successful (Boo, 1993). Figure 2 describes the ecotourism paradigm from a management perspective. Management may refer to local area authorities, non-profit organizations, research teams, and development assistance agencies. These agencies play an important role in encouraging a symbiotic role between the factors. These agencies can help to develop databases for the natural areas, and provide opportunities for resource and economic education, as well as local resource building. Figure 2 can also be used as an evaluative framework of the efficacy of the ecotourism program. The dynamics of each leg of the process can be examined and be used to analyze different interactions. The harmonious relationships between each dimension must be facilitated by management, who are 
important stakeholders in the ecotourism process. Typically, the role of protected area managers can change with an introduction of tourism, but this is more so the case in areas where the authorities have not been used to tourists coming in and viewing the areas.

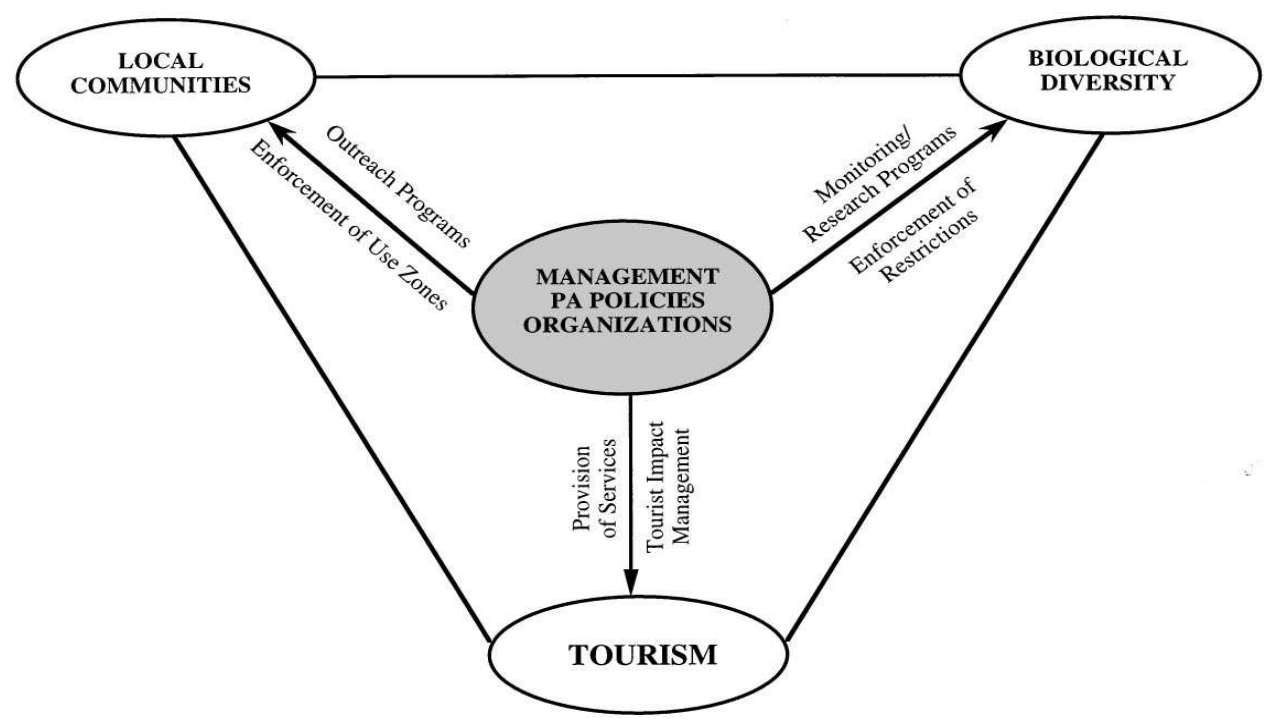

Figure 2. The Ecotourism Paradigm in a management context describes the symbiotic relationship between different stakeholders in ecotourism. From "Ecotourism: Towards Congruence between Theory and Practice”, by S. Ross and G. Wall 1999, Tourism Management, 20(1), p. 130. Copyright 1999 by Elsevier. Adapted with permission.

The management context is a framework that can be applied in sections to an ecotourism project. Some relationships between stakeholders may not exist initially, but they can be viewed as potential relationships. In any scenario, this framework becomes a useful tool for ecotourism managers to analyze possible relationships between key stakeholders. The framework can eventually help facilitate different management programs such as outreach, zone usage, and impact assessment of the ecotourism site. 


\section{Comprehensive and Minimalist Ecotourism as Ideal Types}

From the three core criteria of ecotourism, Weaver (2005) developed a model of ideal types of ecotourism: Comprehensive and Minimalist (Figure 3).

\begin{tabular}{|l|l|l|}
\hline \multicolumn{1}{|c|}{ Criteria } & \multicolumn{1}{c|}{ Comprehensive } & \multicolumn{1}{c|}{ Minimalist } \\
\hline Attractions & $\begin{array}{l}\text { Holistic (nature-based and } \\
\text { cultural) }\end{array}$ & Elemental (nature-based) \\
\hline Learning & $\begin{array}{l}\text { Deep Understanding } \\
\text { Transformational }\end{array}$ & $\begin{array}{l}\text { Superficial Understanding } \\
\text { Non-Transformational }\end{array}$ \\
\hline Sustainability & $\begin{array}{l}\text { Enhancement } \\
\text { Global Environmental } \\
\text { Socio-cultural }\end{array}$ & $\begin{array}{l}\text { Status-quo } \\
\text { Site specific } \\
\text { Environmental }\end{array}$ \\
\hline \multicolumn{3}{|c|}{ High Visitor Satisfaction } \\
& Financial Sustainability \\
\hline
\end{tabular}

Figure 3. The Comprehensive Minimalist Model describes the two ends of ecotourism dimensions. Adapted from "Comprehensive and Minimalist Dimensions of Ecotourism" by D. B. Weaver, 2005, Annals of Tourism Research 32(2), p. 444. Copyright 2005 by Elsevier. Adapted with permission.

A comprehensive ecotourism experience will be holistic in nature, facilitate a clear understanding of the ecosystem and human interface, and the transformational experience will aid improvement of local communities. In contrast, a minimalist experience tends to be site-specific and fosters only a basic understanding of the ecosystem. Both dimensions, however, have the common goals of attaining financial sustainability as well as visitor satisfaction, without which no ecotourism venture would be successful. 


\section{The Modified Comprehensive Model}

Ecotourism can also be classified into hard and soft scales (Weaver, 2005). Typically, the hard end of the spectrum implies a smaller scale of operations and the soft end of the spectrum implies a larger scale of operations. While the hard forms of ecotourism are difficult to find in the real world, it is the model that ecotourism destinations should aim for with a view of reaching sustainability goals. In that light, a Modified Comprehensive Model (Figure 4) was developed by Weaver (2005). It builds on the comprehensive model, and allows for larger groups, different levels of physical activities, and high levels of services.

The Modified Comprehensive Model does not claim that tourists exist in the two extremes of primitive and developed, but assumes the model to be ideal types. Most tourists typically tend to fall in categories between the two extremes. This model helps ecotourism managers to cater to different types of ecotourists and get a clearer direction of their activity pattern.

With the Modified Comprehensive Model, even large package tour groups can be accommodated under the umbrella of the developed setting. This caters to a majority of the tourist crowd, offering many amenities along with a more comfortable level of activities. The primitive setting caters to pure ecotourists, who prefer more physically challenging activities with fewer amenities. 


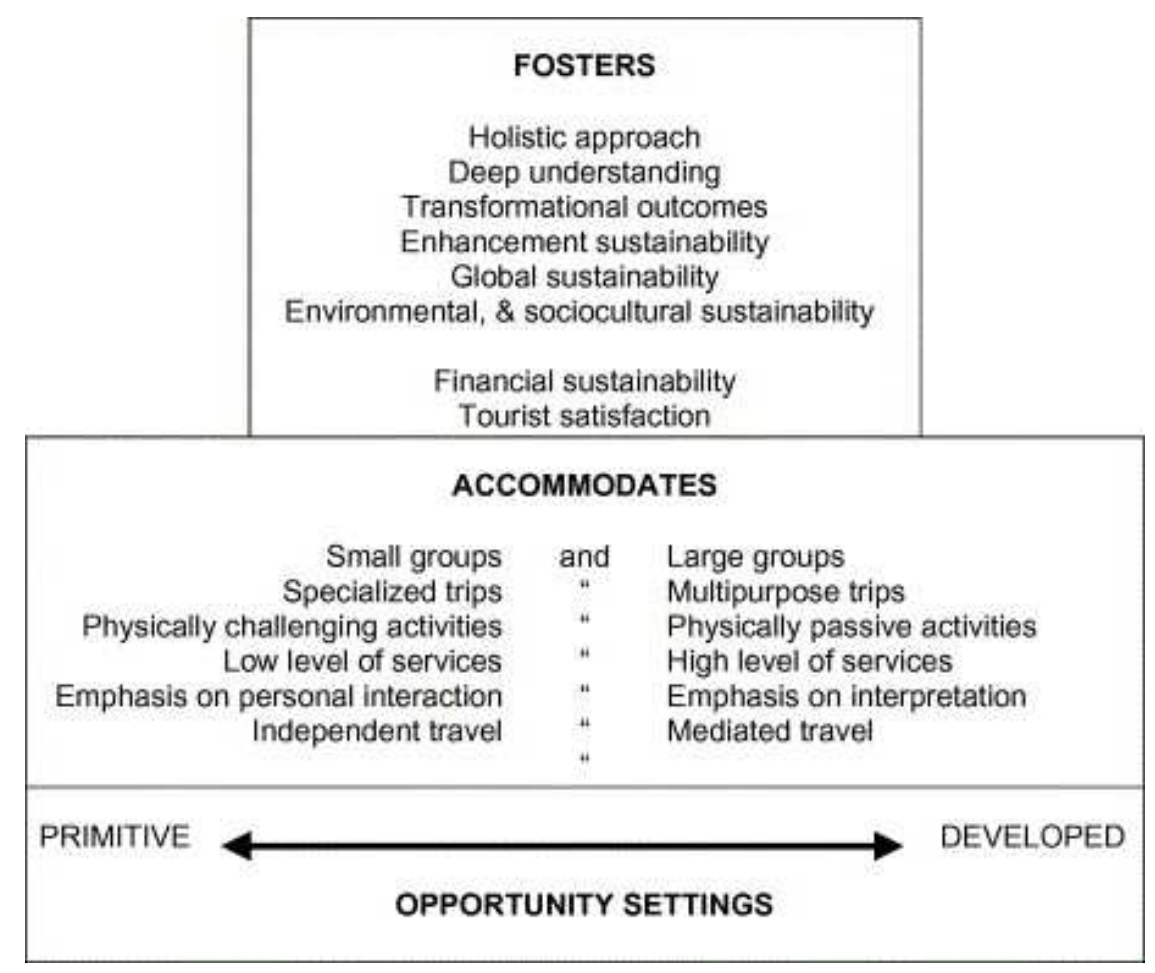

Figure 4. Modified Comprehensive Model. Adapted from "Comprehensive and Minimalist Dimensions of Ecotourism" by D. B. Weaver, 2005, Annals of Tourism Research 32(2), p. 449. Copyright 2005 by Elsevier. Adapted with permission. 


\section{Literature Review}

There has been a great deal of attention over the last few decades directed towards defining an acceptable definition for ecotourism, but this remains elusive. However, it is generally acknowledged that for a form of tourism to be classified as ecotourism, three components are crucial, namely: (a) the tourism must be nature-based (Blamey, 2001; Weaver, 2005) with low environmental impacts paired with conservation benefits (Pearce \& Ocampo-Raeder, 2008), (b) the tourism managers must provide opportunities for learning or education of the tourist, and (c) management must be focused on environmental and socio-cultural sustainability (Blamey, 2001).

\section{Nature-Based Component}

The nature-based aspect can be viewed as a continuum, where, at one end, the ecotourism destination can feature an entire ecosystem, like a redwood forest, or an entire coral reef. This is the holistic and desirable end of the ecotourism spectrum, which showcases an integrated whole landscape. On the other end of the spectrum, there is an elemental approach, which showcases individual megafauna like pandas in China, or megaflora like big redwood trees in California. It is unlikely that the socio-cultural angle will be given much importance in the elemental end of the spectrum. It can be added that hardly any destinations are completely free of human influence anymore (CeballosLascurain, 1987; Valentine, 1992). 


\section{Learning and Education}

The education aspect is the fundamental differentiating factor of ecotourism from other forms of nature tourism. Learning can be facilitated through simple guided tours, hiking, or other forms of direct interpretation. Parks in the United States attempt to provide both formal and informal forms of interpretation (Weaver, 2005). It is important to note that personal forms of interpretation, such as docent-led walks, are more effective at communicating a message than impersonal forms of communication like signage and

brochures. Ideally, the ecotourism experience should foster a holistic understanding and appreciation of the entire ecosystem and its value in terms of global and local sustainability (Fennell, 1995, 1999; Tisdell \& Wilson, 2001).

\section{Management toward Sustainability}

Weaver (2005) argues that there is no contention about the concept of sustainability, but the debate surrounds knowing whether management actions of an ecotourism project are truly sustainable. Added to this is the real controversy of what exactly is to be sustained (Hall \& Lew, 1998). The uniqueness of each destination compounds the factors to be evaluated for sustainability, so factors at one ecotourism destination may not be of value at another destination (Weaver \& Lawton, 1999).

Since ecotourism has no strict boundaries of definition, it can lead to an assumption that any form of ecotourism is inherently sustainable, with minimum or no negative impacts. This notion has led to exploitation in developing countries, where luxury resorts 
in the midst of ecologically fragile regions have been advertised as ecotourism. For example, in the northern Sulawesi region of Indonesia, ecotourism was introduced in three biodiversity rich regions, which were also sites for heavy timber extraction. The expected harmony of conservation, local participation in ecotourism activities and economic benefits, as well as cultural exchanges did not occur (Ross \& Wall, 1999). Due to lack of funding, the envisioned community participatory management plan was not implemented. Thus, local participation was limited to a few powerful tour operators, and subsequent poverty led the local population to illegally extract resources from the forest.

In the Kakamega forest of western Kenya, illegal logging, burning of wood for fires, and other extractive activities were drastically reduced by the conversion of the area into a nature reserve (Bleher et. al, 2006). Where in some cases ecotourism was considered harmful environmentally, socially, and culturally, in this region of Kenya, the greatest human impact on the forest was logging, which reduced with the introduction of ecotourism.

\section{Ecotourism in the United States}

Scholars argue that if the broad principles of ecotourism are followed, including a direct contribution towards protection and conservation of the area used, the geographical area can be a developing country or a developed first world country (Valentine, 1991; Valentine, 1993). Australia was one of the first developed countries to develop ecotourism in the Ayers Rock region, which allowed indigenous, marginalized cultures to earn their livelihood on their terms. The ecotourism projects gave the aboriginal 
communities employment opportunities that had previously not existed. Cultural tours, arts and crafts tours given to tourists became successful. Some of the individuals in the community, however, preferred not to get involved in the tourism directly because the unfamiliar skills needed by the industry were too foreign (Altman \& Finlayson, 1993). New Zealand offers a similar climate as an example for developed country ecotourism (Che, 2006).

Less exotic areas such as northern Canada have become popular ecotourism destinations for fishing and hunting. Canada introduced the concept of an ecotour as early as 1978 to provide an enhanced sense of Canadian identity through the interpretation of its natural environment and resources (Fennell, 1998). The exotic varieties of cultures found in a developing country are missing in most developed nations. In developed countries, however, there are vast landscapes that offer various similar ecotourism activities for tourists. When compared to developing countries, stricter rules and management practices prevail in developed countries, and thus, a more balanced form of sustainable tourism development is possible.

Scholars (Bjork, 2000; Boo, 1990) argue that there is a distinction between naturebased tourism and ecotourism, mainly the learning or education component. In the United States, forests have been altered intentionally or unintentionally for recreation, agriculture, industry, and housing development or similar activities (Irland, 1999). In northern Pennsylvania's Forest County, the economy has been based purely on extraction of hardwood from the Allegheny forests. Timber provided the first tier of employment in 
the area, but did not address the problems of unemployment for the local population. With the introduction of ecotourism, a wider section of the local community became involved through providing accommodation, gas, food, and other amenities to tourists. Old growth forests in particular, were aesthetically important to environmentally conscious tourists, as were the bird species found there.

In Pennsylvania, the remaining old growth trees were of no commercial value, unlike the redwoods, which command great commercial value, thus resulting in conflict between timber and conservation interests. As environmental pressure to reduce timber harvesting increased, there was an urgency to diversify the local economy's employment opportunities. Much of the forest did not have developed roads, and constructing a road network was not a viable option. Ecotourism development required no heavy investment and assured the community of a source of revenue. It was hoped that along with economic benefits, ecotourism would provide an opportunity for a multiple-use local economy, where resources from the forest could continue being used. To cover the costs of replacing timber revenues, it was determined that aggressive promotion and government support in funding would be required. Ecotourism as the sole activity for supporting the entire community was not considered a viable option (Che, 2006).

The western part of the United States had seen a very different reaction to the extraction of timber in the redwood forests. Among the 12 counties in California that have redwood forests, three counties have the greatest percentage of these forests: Mendocino, Del Norte and Humboldt (Stewart, 2007). In the last two decades, timber 
based activities have declined in these forests and many land owners are finding it difficult to maintain these lands, given the increased environmental impact mitigations. Redwood parks in general, have had a visitor decline by $6 \%$, but beach visitors had increased by $13 \%$. Local day tourism is not sufficient to generate adequate revenues to support local economies and act as a substitute for timber extraction. Overnight stays by tourists can generate more revenues by paying for amenities like accommodation, food, and gas.

Humboldt County in California has some of the largest tracts of redwood forests. There is also a presence of Native American tribes, who have sacred burial and cultural sites in the forests, and guard the land protectively. Due to these factors, ecotourism could be developed as a viable alternative to resource extraction and land degradation (Doremus, 1999). Tourism is already an industry in the region, and management practices that enforce strict monitoring of tourism impacts, especially negative environmental impacts, could see ecotourism as a sustainable alternative to resource extraction.

Tourism to natural and protected areas worldwide has increased exponentially, prompting management agencies to seek enhanced visitor management including communication aimed at influencing tourists' behavior to reduce impacts and strengthen conservation stewardship (Brown, Ham, \& Hughes, 2010; Ryan \& Dewar, 1995). Interpretation and education programs need to be designed specifically for a protected area and for the most effective education, it must fulfill two conditions: a) The message 
must relate to an emotional connection that is made in the mind of the tourist, and b) The message must be profound to both protected area managers and tourists (Boon, Fluker \& Wilson, 2008; Ham \& Weiler, 2003; Orams, 1996).

Local participation is one of the most important factors for ecotourism to be successful and sustainable. While moving from an economy of timber and resource extraction to an economy of ecotourism, support for conservation is maximized if benefits from ecotourism potentially match benefits that were available from the extractive activities (He et. al, 2008). An unequal distribution can lead to a failure of the ecotourism model and conservation purpose. If consistent support from the local community is desired, it is vital to ensure that tourism benefits of the local community and benefits to the tourists are well-balanced. When the local community is assured of benefits from tourism, their involvement will help mitigate negative impacts of tourism. The process will also educate the locals about environmental issues in the region, provide the local economy with part-time employment, and finally improve the visit of the tourist (Jacobson \& Robles, 1992).

The United States is one of the biggest markets for ecotourism destinations across the world. Surprisingly, there is a paucity of ecotourism-based operations in the country (Bryan, 2008). There is noticeably less biodiversity than Central or South America, but there are vast landscapes and numerous ecotourism opportunities, along with better management techniques than has been observable in developing economies. In regions such as the Rockies, Alaska, Hawaii, California, the Carolinas, ecotourism can be a 
viable option, but this development would be practical only after understanding the nature of tourism and the tourists in these regions. Accountability to the local environment and surrounding communities also need to be addressed before developing tourism practices here.

In most tourism and ecotourism ventures, volume and capacity dominate most policies and procedures (Bryan, 2008). In national and state parks in the United States, policies and procedure are purportedly made based on reasons other than profit and visitation numbers. However, in 2012, seventy state parks in California were scheduled for closure due to a lack of funding from Sacramento (Graham, 2011). The basis for choosing 70 parks was visitation numbers and ease of closure. Thus, whether written or not, it was evident that popular parks with high visitation numbers will face far less risk of closure at any time.

In most parks of the United States, visitation demonstrates the 95/5 rule (Weaver, 2005). Usually, $95 \%$ of the visitors confine themselves to 5\% of the park, thus leaving $95 \%$ of the park to $5 \%$ of the hard, comprehensive ecotourists. Typically, revenue from the $5 \%$ can be used to maintain the remaining $95 \%$ of the park.

The concept of a multiple-use forest is popular with many proponents of a balanced resource use and conservation ideal. Limiting extraction to second growth forests and setting aside older forests for tourism purposes can be explored (Bosch, 1971), but the commercial value of larger trees is far more valuable than the tourism income that is usually generated. In an older forest, where timber extraction is a concern, the non- 
economic values of the forest need to be assessed. For instance, in a study of the Monteverde Forest Reserve in Costa Rica (Menkhaus \& Lober, 1996) each tourist's visit was calculated at $\$ 1150$. Approximating the number of tourists who visit the area, a comparison of the total revenue from tourism and the revenue from timber extraction was made. If the revenue generated from tourism could meet the revenue from timber, it could be a step in developing appropriate ecotourism policies and practices.

Non-economic values of forests are extremely difficult, if not impossible, to calculate (Gossling, 1999). The conservation of a forest because it is a forest is not sufficient justification for most. Ecotourism activities, when carried out in a sustainable manner, have a high direct use value and this should be an incentive for conserving forests. A qualitative cost-benefit analysis can evaluate the benefits of ecotourism and traditional uses of the area being used for ecotourism. A factor considered is the environmental damage cost, which is the carbon emission and resource use by tourists to get to the ecotourism site. Non-economic values of a forest can be given more relevantly by tourists' motivation to travel to an ecotourism destination. Important elements of a trip for a North American ecotourist are shown to be the wilderness setting, followed by wildlife viewing, hiking or trekking, and visiting national park or other protected area (Wight, 1996).

The tourist is a crucial part of the tourism development process. Many elements at a tourist destination are based on the tourists' motivations, yet little research has been done on what a tourist thinks of a tourist destination and the environmental issues that surround 
it. Ballantyne, Packer, and Hughes (2009) conducted a study at the Mon Repos Conservation Park in Queensland, Australia, where they explored the willingness of tourists to imbibe conservation ideas and messages, especially with regards to wildlife tourism. Tourists were also assessed for their interest and awareness in conservation topics. The study concluded that tourists who visited the park were increasingly concerned about conservation issues and were eager to be a part of minimal impact activities. The tourists were willing to prioritize conservation and minimal impact above their own comfort and experience, which was encouraging to conservationists and tourism managers.

Willingness to pay is a facet of tourism demand that must be accounted for. If any conservation can be funded by tourists who visit and use the area, it is important to find out how much tourists are willing to pay, especially if they are aware that the funds go into protection of the resources. Wildlife viewing was an element that tourists were willing to pay higher costs for in a study conducted in Namibia. The results showed that there would be a surplus of funds that could be used towards conservation measures (Barnes, Schier, \& van Hooy, 1997). Many conservation efforts go awry due to the drying up of funds that may come from sources other than from the tourists. Measuring use values from tourists who visit the ecotourism area has been quite successful in many parts of the world, where tourists pay a certain fee to enter and access the protected area. Non-use values can also be a major source of funding for protecting areas and forests. These may entail periodic membership fees or donations from the general public, who may or may not use the protected area (Dharmaratne, Sang \& Walling, 2000). Assessing 
the willingness to pay for non-use values can represent and forecast better planning of conservation efforts.

The United States, being a large market for nature-based travel, can develop ecotourism destinations. However, it is important for developers and travelers to realize that ecotourism is less about a fashion with stereotypical settings in poor countries, such as in a rainforest environment with giant bugs and animals (Pearce \& Ocampo-Raeder, 2008), but more about guiding principles of environmental and social awareness and accountability. Pearce and Ocampo-Raeder (2008) argue that if ecotourism destinations did not use the label ecotourism, visitors would be less likely to transfer their positive experiences into broader participation.

Probably the most important factor to be considered at all stages of an ecotourism venture is the reaction of the local people, some of whom may be participating and some of whom may not be participating. Conservation cannot be guaranteed in the long run if there is no cooperation from the local population (Koch, 1991). Also, conservationists and ecotourism developers often think that local populations have the same sense of devotion and empathy for conserving the natural resources of the area (Boonzaier, 1996), along with promoting tourism. Even with tourists providing the economic support for many communities, it cannot be assumed that all of the local population has the same values and opinions as the conservationists. For instance, many tourist service providers feel that though they depend on the tourists for their livelihood, tourists represent an unnecessary burden and intrusion into the locals' lives. 


\section{Redwoods and Ecotourism}

One of the most valuable timber trees in California is the coast redwood, in demand for its light weight and resistance to decay, termites and fire (Barbour et al, 2001). This gigantic species of trees can grow up to a height of 367 feet or 122 meters, with a width of over 22 feet at the base. Three species of trees are usually referred to when using the term redwood: Sequoiadendron giganteum (giant sequoia), Metasequoia glyptostroboides (dawn redwood), and Sequoia sempervirens (coast redwood). Coast redwoods occupy an irregular belt between five and 35 miles wide along the north coast of California and the southern coast of Oregon (Noss, 2000). Prior to European settlement, redwoods were not heavily impacted by human activity. As the need for lumber increased with the spread of human settlements in the region, redwood stands fell to a spate of extraction. As technology improved, the lumber industry boomed in California, but even with cycles of increases and declines in redwood extraction, heavy removal of trees has caused a massive reduction in old growth acreage (Russell, 2000). Currently, only about $5 \%$ of the original old growth redwood forests remain and a number of species that are dependent on these forests have become vulnerable to extinction.

An ecosystem cannot survive in its entirety as small fragmented tracts in an environment drastically altered by humans. The diversity and ecology of such tracts can change irreversibly and may even lose much of their diversity and the ability to grow giant trees like the old growth (Noss, 2000). A redwood tree has an approximate lifespan of over two thousand years resulting in the giant trees seen today. But with heavy timber 
extraction, and the opinion that trees are a renewable resource that can grow back to the massive size they were, these forests may never regain their original stature.

Ecotourism has been suggested as a means to conserving fragile environmental systems as well as generating revenue (Gossling, 1999; Ruschmann, 1992). Since ecotourism is primarily a developing country concept, sound economics and management become imperative in these projects. Ecotourism in developed countries can be implemented more easily than in developing countries, as management policies, political stability, and environmental consciousness provide a more stringent approach to protection.

Since redwood forests exist primarily in developed countries, the possibility of protecting them through generally accepted ecotourism norms has not been explored seriously in the United States. Recreational activities can be promoted in redwood forests to generate some revenue as against revenue generation from resource extraction.

The purpose of this study is to assess the possibility of implementing ecotourism in coast redwood state parks in Santa Cruz County in California to generate revenue so that there is an additional impetus to conserve the remaining redwoods. Perceptions of the public and state park employees towards habitat conservation and ecotourism will be explored and analyzed through this study. 


\section{The Significance of Charismatic Flagship Species}

Ecotourism as a tool to ensure conservation and generate revenue is being implemented across the world, but there is substantial evidence that many projects fail for a variety of reasons. The presence of a flagship species is usually an indicator that visitors will come to the area in large numbers, but this influx depends greatly on the natural attraction itself. For example, in Rwanda, gorilla tourism generated revenue and tourist influx in spite of the political instability. The flagship species, the mountain gorilla, was considered attractive enough to risk daring the situation of the country (Kruger, 2005). Ecotourism was also suggested as a tool to protect the rare rockfowl in West Africa, but the species was not considered spectacular enough to generate revenue that could alone sustain the project (Salewski, Goken, Korb, \& Schmidt, 2000).

Anthropogenic mismanagement is the leading cause for an irrevocable reduction in species diversity (Diamond, 1994). A flagship species can also be called a keystone or indicator species, and symbolizes the charismatic nature of a particular species (Entwistle $\&$ Dunstone, 2000). Examples include both species of redwoods and the rafflesia flower of Indonesia, and tourism projects focusing on these are largely driven by consumer demand and public perception (Fennell \& Weaver, 2005; Weaver, 2005). On the other hand, using large megafauna or flora as a charismatic tourism species limits the application of the concept to these species alone, even though other particular species in the same ecosystem may be in a critical state and in dire need for conservation (Pickering \& Ballantyne, 2012; Verissimo et al., 2009). Though charismatic species have created an 
impetus for conservation, there are few studies on the impacts of conserving for a single species instead of the entire ecosystem.

Flagship species are also a key factor in marketing for conservation and raising public support. Due to this, selection of the appropriate species is essential (Home, Keller, Nagel, Bauer, \& Hunziker, 2009). Management of a single species versus management of the entire landscape has been in continuous debate amongst scholars. However, proper management of an entire ecosystem as a landscape is one answer to conservation of a single flagship species (Simberloff, 1998). 


\section{Research Objectives}

The mission of California State Parks is to provide for the health, inspiration, and education of the people of California by helping to preserve the state's biological diversity, protecting its most valued natural and cultural resources, and creating opportunities for high quality outdoor recreation. Ecotourism in redwood parks represents a unique opportunity to build on the visitor foundation that has already been laid by the California State Parks system. Santa Cruz, California is highly dependent on tourism, but at California State Parks, there exists a loyal base of visitors to some of the most magnificent coasts redwoods available to the public in this region. Initiating sustainable ecotourism would also give state parks an added impetus to protect and manage the redwoods ecosystem.

This study addressed the following over-arching research question:

Do redwood state parks in Santa Cruz County, California have the potential to become ecotourism destinations?

Four general areas of interest directed this study:

1. Nature-based component: How are natural resources managed in the redwood state parks in Santa Cruz?

2. Learning and education opportunities component: What is the role of the state park system in providing educational opportunities to tourists about conservation of redwood parks? 
3. Management towards sustainability component: How is the natural environment and local communities sustained in the redwood state parks?

4. How do tourists view redwood parks and what are their expectations while visiting redwood parks? 


\section{Method}

This study utilized a multi-method approach to collect data and arrive at results. The study used in-depth semi-structured interviews and short multiple-choice visitor questionnaires to arrive at a range of responses required to answer the research questions. Qualitative methods were required due to the nature of the research questions and the depth of data that were required. Quantitative methods were adopted to compute results of the visitor survey that collected responses from 150 tourists at Big Basin Redwoods State Park in Santa Cruz County.

\section{Study Area}

Commercial logging began in Santa Cruz in the 1850s. After several decades of extensive logging, Santa Cruz is now under some of the strictest logging rules California. The Ohlone Indians or Costanoans lived in the region for thousands of years and also used fire as a management tool. After the first recorded Spanish exploration came to the area, European immigration to the area increased dramatically. The California Gold Rush also brought hordes of people to San Francisco and the demand for lumber led to extensive logging operations (Stephens \& Fry, 2005). Today, the forests of Santa Cruz are rigidly protected with logging rules in place and almost all the old growth trees are permanently protected. 
This research focused on the redwood state parks of Santa Cruz County, namely, Big Basin Redwoods State Park, Henry Cowell Redwoods State Park, the Forest of Nisense Marks State Park, and Portola Redwoods State Park (Figure 5).

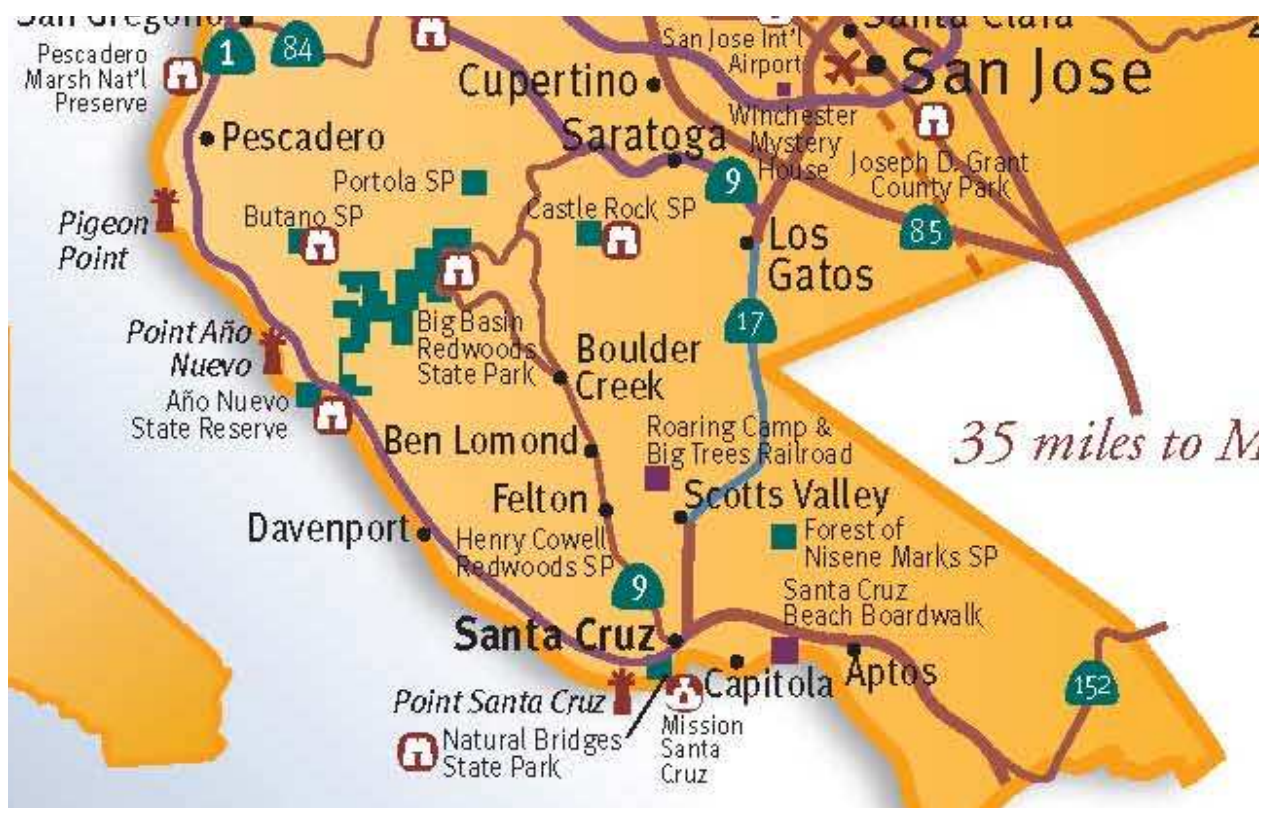

Figure 5. Location of Santa Cruz County Redwood Parks. Adapted from California State Parks. Retrieved December 2012 from http://www.parks.ca.gov/pages/861/files/pdf

Big Basin Redwoods State Park. Big Basin is arguably the most popular and famous park amongst the four parks, along with being the oldest, established in 1902, in California (Figure 5). In the last decade, the average visitor numbers have ranged from 1.13 million visitors in 2000-2001 to 641,311 visitors in 2010-2011 (“'Our History and Legacy”, n.d.). 
The history of Big Basin Redwoods State Park dates back to the late 19th century. In 1899, San José photographer Andrew P. Hill was on assignment in Northern California's Santa Cruz Mountains (“Our History and Legacy”, n.d.). While Hill was photographing a very large redwood tree in what is today Henry Cowell Redwoods State Park, the owner of the grove, Joseph Welch, stopped him, accused Hill of trespassing and demanded the negatives. Hill refused, but irate that the redwoods were not accessible to the general public, he returned to San José and started a campaign to save the coast redwoods of the Santa Cruz Mountains. At a time when widespread logging was taking place all over the Santa Cruz Mountains, Hill arranged a meeting of scientists and influential people to discuss what could be done to protect the redwoods. On further exploration, they discovered that the region that is today Big Basin Redwoods State Park had bigger trees and was designated for logging. Soon after, they formed the Sempervirens Club.

The Club committed to lobby for the protection of the redwoods and for the creation of a public park at Big Basin ("Our History and Legacy”, n.d.). For over two years, the Sempervirens Club members lobbied for the creation of a state redwood park in the Santa Cruz Mountains. Effective lobbying by Hill and the other members of the Sempervirens Club convinced the California Legislature to pass a bill in 1901 allowing for the creation of the park.

In 1902, the state of California bought 3,800 acres of ancient redwood forests in Big Basin, preserving coast redwoods for the first time (“Our History and Legacy”, n.d.). 
California Redwood Park, later named Big Basin Redwoods State Park, was the first park established in California in the current state park system.

The park is divided into two areas, the uplands and the coastal areas ("Our History and Legacy," n.d.). The uplands contain second growth and old growth redwoods along with chaparral, manzanitas, Pacific madrones, mixed conifer, and oak. The coastal region is recognizable by beaches, shrubs, grasses, marshes, knobcone pines, and flat terrain. The park provides important habitat for several endemic wildlife species and is of great importance to regional wildlife populations. Big Basin Redwoods State Park is home to several special status species including the California red-legged frog, the San Francisco garter snake, the coast horned lizard, the marbled murrelet, the American peregrine falcon, the western snowy plover, and the mountain lion.

Henry Cowell Redwoods State Park. The same Joseph Welch who chased Andrew Hill off his property ran a very successful resort adjacent to what is today Henry Cowell State Park (Jones, n.d.). Industrialist Henry Cowell purchased 6,500 acres of forest in 1865 , adding to his quarrying and lime operations. This property was adjacent to Big Trees Resort and in the 1920s, the Welches raised support from the Santa Cruz County to buy and preserve their virgin redwood lands. Eventually Samuel Cowell, the last of the Cowell line, donated the rest of the park to the state, but only under the condition that Santa Cruz County also give up its portion of the land (Big Trees Park) to the state so that it could all be managed together. Thus, Henry Cowell Redwoods State Park was officially created on August 18, 1954. 
The park comprises over 4,000 acres today, and is one of the most popular redwood parks in Santa Cruz County (Jones, n.d.). The state park is hilly and with old and second growth redwoods dominating the flats, while the park's hills are covered with oak woodland, ponderosa pine, and maritime chaparral. Animals in the park include raccoons, mule deer, coyotes, silver salmon, steelhead, and banana slug. Henry Cowell Redwoods State Park is more of an urban park surrounded by the town of Felton (Figure 5). The park sees high visitation from local communities and school groups as well as other tourists. With easy access to freeways and other cities, the park also sees large coach tour groups, especially during the summer and holiday seasons.

The Forest of Nisene Marks State Park. The steep and dark forests of Aptos held no real value for the Spanish and Mexican settlers who settled in the Monterey Bay Region in 1770 (“The Forest of Nisene Marks State Park General Plan”, 2005). In 1833, the land was granted to Raphael Castro, who used the land for his livestock, but did not venture into forbidding redwood forests. In 1883, the Loma Prieta Lumber Company took over and by the time they sold it to the Marks family in the 1950s, more than 140 million board feet of redwood timber had been extracted from the region. By 1955, the Marks family acquired over 9,000 acres of redwood parcels. The combined lands were named after Nisene Marks, the matriarch of the Marks family, who died in 1955. The family then donated the land to California State Parks and the Forest of Nisene Marks was established in 1963. 
Due to the efforts of the Sempervirens Fund and Save the Redwoods League, an additional 1,000 acres were added gradually to the boundaries of the park ("The Forest of Nisene Marks State Park General Plan”, 2005). The park contains five plant communities, namely, grassland, scrub and chaparral, woodland and forest, riparian, and marsh. The plant communities include purple needle grass grassland, northern maritime chaparral, redwood forest, red alder riparian forest, and coastal and valley freshwater marsh. Although Nisene Marks has been clear cut, older second growth redwood stands provide a habitat for several species of birds such as the stellar jays and thrushes, smaller mammals such as raccoons, and wood rats. Surrounded by the community of Aptos, the park is an extremely popular destination for hikers, bicyclists, and horseback riders (Figure 5). Nisene Marks does not have a campground, and offers a more rugged terrain for adventure sport enthusiasts.

Portola Redwoods State Park. Portola lies in a natural basin forested by coast redwoods, Douglas fir, and oaks ("The Making of a State Park", n.d.). Portola Redwoods State Park was named for explorer Don Gaspar de Portolá, who led an expedition in search of Monterey Bay in 1769. The park houses two creeks, Peters and Pescadero. Most of the redwoods are second growth trees (Figure 5). This park, like much of the Santa Cruz Mountains, was logged during the 19th century. Much of the logging at Portola was for shingle production and these needed trees that were straight and thus, were selectively cut. Due to this reason, many large trees remain today and can be seen in the park. 
From 1924 to 1945, the Islam Temple Shrine of San Francisco owned the property and used it during the summer months as a retreat for its members ("The Making of a State Park", n.d.). In 1945, the state of California acquired the land. During the 1960s, Portola was used as a resort: Pescadero Creek was dammed to provide for a large fishing and swimming area for visitors. In 1974, the dam was removed and Portola continued to be used for camping, hiking, and other similar activities.

Dense redwood forests combine bay laurel and tan oak with huckleberry, redwood sorrel, and native ceonothus ("The Making of a State Park", n.d.). The canyon walls show marine deposits from an erstwhile underwater landscape. The campground sits beneath the forest canopy and is home to various bird species, blacktail deer, coyote, raccoon, and banana slugs. Portola was threatened with closure in July 2012 due to state budget cuts. However, donations from Save the Redwoods League, Peninsula Open Space Trust, Portola and Castle Rock Foundation ensured that the park would be kept open for a year. Later on in 2012, California State Parks announced a moratorium of two years on all the seventy state parks slated for closure, including Portola.

\section{Tourism in Santa Cruz}

Santa Cruz County is located on the California coast, situated at the northern tip of Monterey Bay, sixty five miles south of San Francisco, and thirty five miles southwest of the Silicon Valley (http://www.santacruzca.org/partners/tourism-facts.php). It has a Mediterranean climate and sunshine for about three hundred days a year. Santa Cruz 
County has twenty nine miles of beaches several state parks and beaches. Santa Cruz County's economy is heavily supported by agriculture and tourism.

Santa Cruz is one of America's surfing capitals and has a museum dedicated to the sport. The beaches, whose waves are known all over the world, are the most popular tourist draws round the year (http://www.santacruzca.org/partners/tourism-facts.php). The beaches are considered to be amongst the most pristine in the country, with visitors thronging to the beaches to engage in surfing, swimming, kayaking, paddle boarding, and other similar activities. Santa Cruz also offers several state parks that have been set up to protect the natural and cultural resources of California. The most popular state parks include Ano Nuevo, Big Basin, Henry Cowell, and Natural Bridges, among others.

A visitor profile report from the Santa Cruz County Conference and Visitors Council shows that approximately $19 \%$ of the three million visitors who come to Santa Cruz County choose to visit redwoods (http://www.santacruzca.org/partners/tourism-facts.php). Especially in the summer, most visitors choose to visit the beaches rather than redwoods. The tourist market is driven mostly by the San Francisco Bay Area and the Central Valley area, and is marketed as such. Most visitors tend to be domestic tourists and revenue from tourism accounts for over $\$ 600$ million in revenues each year.

\section{Status of California State Parks}

On the 13th of May 2011, Governor Brown issued a list of 70 California State Parks that were to be closed indefinitely to the public (Graham, 2011). The cited reasons were 
lack of money and lack of personnel to manage the day to day running of the parks. Portola Redwoods State Park was one of the parks slated for closure in July 2012. By all accounts, California State Parks brought in more money and revenue to state coffers and local communities than it cost to run them, not to mention the intangible health benefits that parks brought in to communities.

The argument of the public and press was that closure of a park was, in effect, a path to vandalism, abandonment, and deterioration (Graham, 2011). If the parks had to be reopened at any point in time, the startup costs of repairing and re-conditioning would be significantly higher. Graham (2011) summarizes that local businesses and communities that depended heavily on these parks to provide tourism dollars would be destroyed and thousands of jobs would be lost.

Just as the date of closure was looming, an audit of the California Department of Parks and Recreation revealed a hidden surplus of fifty four million dollars (McGreevy \& Megerian, 2012). Organizations that had donated considerable monies to state parks demanded their money back. Amid the scandal, a bill was passed signing a two year moratorium to keep all parks on the closure list open. The bill provided forty million dollars to address maintenance issues and to keep all parks open, including Portola Redwoods State Park. 


\section{Study Design}

Using a multi-method approach of qualitative and quantitative methods, this study relied on the grounded theory method for analyzing qualitative data and relied on descriptive statistics for analyzing quantitative data. Grounded theory involves the collection of data and analysis through key themes that emerge in the data. These key themes, alternatively called codes, are further analyzed to arrive at the results (Strauss \& Corbin, 1990).

There are several examples of tourism research that utilize mixed methods. This combined approach can enhance the quality of the resulting data because it benefits from the strengths of both quantitative and qualitative data, and the resulting data can be enhanced as the strengths of both qualitative and quantitative data can be increased (Davies, 2003; Jamal \& Hollinshead, 2001). The interviews were investigated using the qualitative sociological framework of naturalism (Gubrium, 1997). Naturalists attempt to present the lives and outlooks of the study subjects as accurately as possible. An important aspect of the naturalism approach is to study the subjects in their natural environment, and this study followed this approach to an extent by interviewing most of the respondents in their offices in the parks. Quantitative data were collected in the form of questionnaires which were administered to tourists in Big Basin Redwoods State Park. The survey consisted of 14 multiple-choice questions and one open-ended question. 


\section{Sampling}

Qualitative data were gathered through a key informant who was a veteran of the state park system in Santa Cruz and agreed to help with the study. A key informant is a person who has specialized knowledge about the subject and has connections to a community that the researcher wants to access (Esterberg, 2002). With the key informant's help, email contacts of several state park employees were obtained. The primary sampling technique used for the qualitative section of this study was snowballing. Starting with the first contact, a purposive snowballing technique was used to get contacts from each contact. Snowballing involves gaining contacts from each contact as an extended association (Esterberg, 2002). In the process, the next contact can refer the researcher to the next participant and so on.

Using purposive sampling in this study involved requesting key informants to provide contacts from different departments of the organization such as referring the researcher to ecologists, rangers, docents, interpreters, volunteers, and supervising rangers. It was the intent of this research that all voices of people in the study be heard; thus, asking broad questions about what the interviewees thought and their opinions was of paramount importance.

Quantitative data were gathered by using systematic random sampling. A random number generator was used for every survey day to generate a number between one and 10. This number determined the frequency for approaching potential subjects. Thus, every nth person who came towards the Visitor Center was asked to answer a survey. If a 
person declined the survey, the process started again, with every nth person being asked to respond. Using this approach, 150 respondents were chosen randomly over the course of the study.

\section{Data Collection}

Qualitative Methods. This study depended on qualitative research methods, specifically in-depth semi-structured interviews. Semi-structured interviews are interviews that contain open-ended questions which allow the interviewer to explore a range of areas. Previously established questions were used to guide the interviewer around the relevant topics and the interviewer followed the interview questions, but also pursued topical trajectories that arose from the responses of the respondents.

A total of 11 semi-structured interviews were conducted with state park employees and docents, including senior interpreters, ecologists, and supervising rangers. The duration of the interviews ranged from $25 \mathrm{~min}$ to $2 \mathrm{hr} 10 \mathrm{~min}$. Interview questions ranged from personal information to extensive questions on resource management, management hierarchy, ecotourism, and interpretation at state parks (Appendix A).

Participants. This study required a selection of state park employees who were in a variety of administrative and management positions. The interviewees were a mix of rangers, ecologists, resource ecologists, interpreters, docents, and seasonal employees. While some individuals were contacted during the survey administration, most of the others were contacted by email. 
Interview Process. Once contacted, the interviewees were emailed the interview questions and research proposal with the information that there might be other follow up questions. Of all the individuals contacted, only one declined being interviewed. All the interviewees agreed to the interview being recorded. Most interviews took place at Henry Cowell Redwoods State Park and Big Basin Redwoods State Park. The staff at Mountain Parks Foundation, a non-profit organization in Henry Cowell Redwoods State Park, declined an interview, but provided some brochures and organizational information.

Some interviewees were brusque and to the point, with no extra information to share. Some other interviewees had a lot of information to share, including personal opinions and ideas. Certain questions, especially questions regarding fiscal policies, took most respondents longer to answer. Questions regarding education and interpretation policies took a considerably short time.

Quantitative Methods. Random sampling procedures were used to survey 150 visitors at Big Basin Redwoods State Park between May 2011 and October 2011. Summer was the busiest season for state parks, and thus, the greatest number of visitors could be accessed then. The highest foot traffic at Big Basin Redwoods State Park was at the Visitor Center, and the California State Parks authorities suggested that the survey table be set to the side of the main door so the table would be visible to all tourists. Only one location was used to collect the surveys. The survey instrument was a fixed choice questionnaire. The results of the visitor surveys were tabulated by each questionnaire, and descriptive statistics were employed to get relevant data. A $t$ test on four specific 
survey questions assessed the statistically significant differences between the means of two groups of tourists.

Visitor surveys consisting of 15 questions (Appendix B) were administered to 151 people at Big Basin Redwoods State Park. Big Basin Redwoods State Park was chosen as the ideal choice of state parks due to its popularity with visitors. Also, when state parks authorities were contacted, they preferred that the surveys be administered in one park instead of setting up survey tables at different parks. One survey had to be discarded, ending the survey at 150 visitors. The surveys were administered every weekend during the study period on both Saturdays and Sundays between 7:30 AM and 1:30 PM. After two weeks, the researcher realized that visitors who came to the park earlier in the day were more relaxed and had more time to answer the surveys. Visitors who came to the survey table after 1:30 PM were in too much of a hurry to be able to answer the questionnaires.

The surveys participants were chosen using a random number generator. A visual determination was made to exclude children from the survey. Some weekends yielded more responses than others. For instance, one day in September yielded only two responses, but one day in July yielded 24 responses.

\section{Data Analysis}

This analysis focused on the researcher's interpretation of the meaning of specific codes and themes to elicit more abstract and overarching dominant themes (King \& 
Horrocks, 2010). As explained in Seidman (1991), the purpose of an in-depth interview is to not only obtain specific answers to specific questions, but also to get personal opinions and experiences which may be related to the issue. The interviews provided a large amount of data, and not all of the data were used in the study as some of it was irrelevant. The final motive here was to relate to the subject's experiences and make meaning of it. During this process, many pieces of information tended to emerge that were not directly related to the research question, but keeping in line with qualitative research, that information was enlightening to the researcher in many ways. It brought about an unforeseen facet of the subject, the research topic, and analysis, which in turn, added to the richness and detail of qualitative data (Esterberg, 2002).

Coding the Qualitative Data. The interviews were digitally recorded and then read thoroughly as the first step of transcription. The interviews were transcribed using VRS (voice recognition software) in the Microsoft suite of tools. The recordings produced over 75 pages of text and sections of the text that seemed relevant and interesting were marked by underlining and parentheses. In qualitative research, it becomes important that the researcher decide what is relevant and important. In a sense, this is subjective and lends a facet of interest to the direction of research (Seidman, 1991).

Re-reading the text can help confirm the judgment and help avoid major errors. Sections were color coded if they were thought to be relevant to supporting the research questions (King \& Horrocks, 2010). Searching the data for similar ideas, themes, and categories gave way to assigning each similar theme or code label. Codes were assigned 
based on reading the text and based on the research questions, consistent with the inductive approach common in qualitative research. Issues in the text were collated under specific codes. Each passage or text that was coded under the same label was judged to be part of the same theme (Miles \& Huberman, 1994). Once meaningful labels were assigned, the text was re-read to ensure no new themes were apparent and that all data fit into the existing code labels.

As the next step, the codes were drawn together in broader and specific themes. As a result of having read the data several times and being aware of specific contexts, the broad descriptive codes were reduced into specific, yet encompassing analytical themes of sub-codes. This was followed in the typical guidelines of grounded theory approach (Gubrium, 1997). When reducing data descriptive codes into analytical themes, large parts of the text or chunks of data came together under the specified themes.

Subsequently, combining each of the broad themes, write-ups were compiled and the whole text was reduced to summaries of each main theme. The qualitative research process followed a logical path (Figure 6). It was an advantage that the large script was condensed into a more conceptual summary, but it was disadvantageous that the summary held the inherent risk of losing details from the original text. 


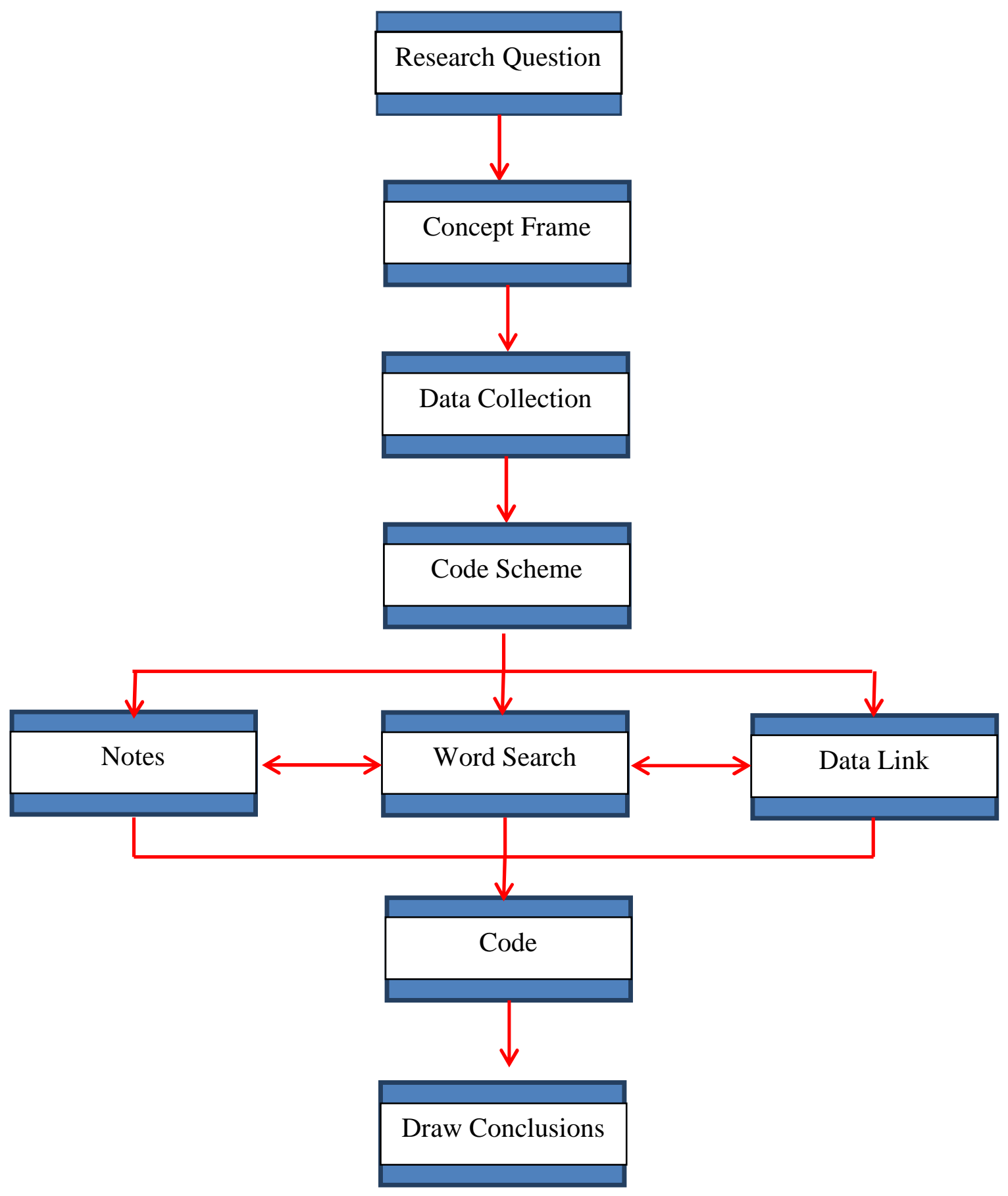

Figure 6. The qualitative research process shows the path from question to conclusions. 
Analyzing Quantitative Data. The quantitative primary data was collected in the form of surveys from tourists at Big Basin Redwoods State Park. The questions in the survey covered areas such as demographics, opinions of tourists regarding ecotourism, visits and number of visits to redwood parks, willingness to pay for conservation of redwood parks, and reasons for visits to redwood parks (Appendix B). The survey ended with an open-ended question seeking suggestions for conservation of redwood parks, which many respondents chose to not answer. The data collected from this was designed to allow for simple descriptive statistics such as averages, frequencies and percentages. Inferential statistics were limited to calculating $t$ tests for four questions of the survey.

Since the responses were fixed-choice questions, a numbered code was assigned to each response. For example, the question, "How many times have you visited this park?" had the choices of "<5 times", "5-10 times", and "> 10 times". The numbered codes were assigned beginning with " 1 " and going sequentially up to the highest number of fixed responses. Thus, in the above example, " $<5$ times" was assigned the code " 1 ", "510 times" was assigned "2", and "> 10 times" was assigned "3". Of the 15 questions, 14 were assigned numbered codes and tabulated in a single Microsoft Excel file.

\section{Limitations of the Study}

The qualitative and quantitative data for this study was collected between May 2011 and June 2012 and as the research was drawing to an end, the state parks were threatened with the closure of 70 parks, including Portola Redwoods State Park, which was a part of this study. The closures were eventually stopped due to a fiscal scandal and the passing 
of a bill which allowed for a two year moratorium on all the 70 state parks. Though these changes may not have dramatically altered the results of this study, it is possible that several facets may have appeared to subtly change the direction of the analysis and results of the study. The semi-structured interviews were conducted based on a snowballing technique, but this technique does not guarantee representative samples.

The tourist surveys were conducted at Big Basin Redwoods State Park and it can be argued that only a certain type of tourist visits Big Basin. By not sampling at the other parks, it is possible that the responses were slightly different from the responses that may have been gathered at the other state parks. 


\section{Results and Discussions}

The objectives of this research included analyzing the potential of Santa Cruz state parks to develop ecotourism. The questionnaire included questions to analyze management policies, environmental policies, tourist opinions of state parks, and educational opportunities to tourists. The interviews with park staff and docents resulted in detailed information regarding management and tourism in state parks. In general, tourists and state park employees were strongly supportive of the idea of developing ecotourism in the redwood state parks of Santa Cruz but differed in their concepts of what they considered ecotourism. The role of docents gave a strong impetus to the potential of ecotourism development in redwood state parks as the docents demonstrated the resilience of the state park system even in times of fiscal turmoil. While a foundation for tourist education and learning was certainly present, the interpretive visitor material did not appear powerful enough to support a transformation of the tourist towards proenvironmental behavior and environmental stewardship.

The tourist survey indicated that all tourists were interested in more in-depth educative and interpretive programs. Resource management objectives such as thinning redwood forests, clearing forests of smaller trees to reduce competition, and the relative leniency with which protocols were developed were called into question. Budgets and lack of financial resources showcased the interconnectedness of this facet with every section of park management. The lack of funding had impacted tourist services, maintenance staff, and employee morale. 


\section{Interview Results}

Most of the interviewees were California State Park employees, and one was a docent at Big Basin Redwoods State Park. The 10 employees had been involved in state parks management for between six and 30 years, while the docent had been at Big Basin Redwoods State Park for nine years. Many of the interviewees had an educational background in environmental studies or natural resource management. In the interest of maintaining confidentiality, the specific employment titles of the respondents have not been mentioned while discussing the results.

When the entire text was read several times, 15 main codes appeared to stand out. As part of the second coding process, these fifteen codes were then clustered under four major themes. These four themes stood out as being able to subsume the other codes, and these major clusters were compared and studied in relation to the research questions. The four major themes were ecotourism, management, impacts, and environmental policy.

Respondents volunteered a great deal of information regarding the fiscal policies and realities of the state park system during the entire interview. The budget was discussed by almost every interviewee even if the question did not refer to fiscal issues.

When asked about the history of redwood parks in Santa Cruz, all the interviewees had similar responses with information similar to state parks brochures' facts and public information. They all spoke of logging history and the formation of redwood state parks due to the intervention of Andrew P. Hill, the founder of the Sempervirens Club. 
Levels of education and employment status seemed to be independent of knowledge about certain areas. For example, while answering questions on climate change concerns, some respondents with advanced degrees were not aware of basic climate change issues, while some other respondents with a high school education were keenly aware of the implications of climate change and conservation. One of the docents showed a remarkable grasp of issues, policies, and their implications in the state park system, but some of the interpretive staff was unaware of any issues outside of their area of education.

Nature-Based Component. The personnel at California State Parks are guided by their mission statement, which is to preserve and protect the unique resources contained within the state parks. According to many of the interview respondents, a lack of funding and staff acted as an obstacle to deter them from completely carrying out their duties.

Resource Management and Tourism Relationship. Within the state park system, discussing management of the park was a sensitive and contentious topic. There was disagreement in what each interviewee opined the current management situation was and what it ought to be. There were a few interviewees who were unsure about the exact hierarchy and stated that the higher up the ladder one went, the clearer the hierarchical structure became. This could be interpreted as lack of structural and organizational transparency at lower positions. While there was general agreement on the division of visitor services and maintenance, there was dissension on what each interviewee thought about his/her job profile. For instance, some employees said there were too many peace 
officers, while several peace officers (also called rangers) who were interviewed said there were too few peace officers. Interestingly, one interviewee, said:

I basically get the sense that they drive around and patrol and don't do very much...I don't think we need these highly paid rangers to patrol all the time and in such great numbers. One of my ranger friends described it by saying, "You work harder than me $95 \%$ of the time."

In contrast, a peace officer said:

There is a huge dearth of rangers. Currently only 300 positions are filled out of a possible 750. So now, I'm covering, with one other colleague, Castle Rock, Portola and Big Basin Redwoods State Parks. Currently we don't have any maintenance staff assigned to the park, we also tend to do a lot of the maintenance duties, and this takes a considerable amount of time.

When asked if there was a gap in policies and their implementation, one senior state park employee noted:

We don't have a gap in management policy and implementation because we are not really manipulating or extracting resources from the park. The park is $100 \%$ protected and thus, there is no conflict of extracting and managing resources. Our biggest challenge is regulating public usage and to providing resources to make sure we're doing that. 
In stark contrast, another employee noted:

There are gaps and there are gaps everywhere. This typically comes from being underfunded and understaffed...there's just no way to fill the gap. This typically comes from being understaffed and underfunded. And the right answer to that is that we prioritize all the time.

A senior natural resources staff member stated:

I'd like to say that the gap comes not from us, but from the visitor services and ranger staff, who are not always familiar with policies. In general I think we have a very good relationship with our ranger staff. I'm sure there are gaps but they're pretty good at managing it.

A senior management employee said:

We don't really have gaps, we actually have very good policies, and the real problem for us is the fiscal reality of the budget; we don't have the money for the staffing levels that we would like to see accomplish all of the management policies. That's been the case with state parks for a long time now. We just haven't been funded to the level that we really need.

It was interesting to note that some employees were of the opinion that there were significant gaps in management and policy implementation, while some others thought 
that the system was almost perfect, with no gaps and no implementation concerns. It became necessary to ask how these issues in management affect tourists or visitors who come to the park and how these management views affect the redwood forest ecosystem as a whole. The discussions regarding lack of funding and a general lack of staff were a part of every major area of concern.

The environmental policies that govern any ecotourism project are of paramount importance because the natural resources are the attraction that brought tourists to the area in the first place. The California Department of Parks and Recreation is governed by the California Environmental Quality Act (CEQA) regulations as the overarching set of regulations that must be followed. While all the interviewees claimed that they had almost no oversight from Sacramento as far as environmental policy goes, they stated that they usually followed the Departmental Operations Manual (DOM) and the Departmental Administrative Manual (DAM). It is worth noting that the Operations Manual (DOM) and Administrative Manual (DAM) are compiled by staff at Sacramento and provide a section on guidelines of natural resources management, which parks employees follow.

Coast redwoods have long been valued for their wood in the United States. Old growth virgin forests and trees remain in smaller pockets along a narrow strip in Northern California (Sun, 2005). As strict logging rules protect most of the old growth redwoods, researchers debate forest management policies of national and state parks that protect the last of virgin redwood tracts on public lands. One side in this issue believes that forest lands need to be managed and the other side believes forest lands need to be left alone as 
nature made them (Russell, 2010). In the case of Santa Cruz County's redwood parks, a majority are urban parks. The practice of "thinning" is described as reducing the density of trees in the forest so as to let the bigger trees thrive, remove fuel from the land, reduce the canopy density, and in general, make the forest more open rather than dense. Some researchers (Dennis-Parks, 2004; Russell, 2010; Sun, 2005) claim that thinning is no more than a masked effort to increase logging in forests, especially on public lands.

There was multiplicity of opinions as regards the environmental policy being followed by state park ecologists and managers. One senior and experienced park employee said:

We have guidelines in the DAM, but these are not specific to the redwood forests, but they are specific to vegetation or forest succession. These guide us in everything that we do. I couldn't find anything specific to the redwoods: I did spend a little time looking for it. I may have missed something. It's probably covered under our general vegetation policy, and that will guide what we call vegetation management statements.

Talking of thinning and forest management, one park employee said:

I like to think that we're addressing things that are at the highest priority, but there are a lot of places that I'd like to point out and things that I'd like to do, that we're not doing. The idea of forest/mechanical thinning of the forests, I think it's fair to say that there's a future to that, but we're not doing it. I'd like to. 
And:

The forest evolved with much larger spaces in between, and that affects everything, nutrients and what can grow there. It changes the whole ecology. So thinning is a way to try and mimic natural disturbance...it's going in and understanding what spaces should be and what makes most sense.

The interviewees responded differently when they discussed thinning. One subject said:

It's going in and physically marking trees that are overcrowding and then people come in and remove them...there is no prescription that fits everything. It's based on the beliefs of the person writing the prescription. Politics can really influence this.

And:

We've talked about thinning; it may be the next big thing we want to get into. I've been excited about thinning for a really long time. And going back to the Steve Sillett studies, we know that the larger trees put on more biomass. So if we were to go through and thin, we would be able to encourage carbon sequestration, just because you do this thing called a release in a tree, where you basically take away some of its competition, when you look at the growth rings after you cut it 
down, you'll find an explosive amount of growth in a very short period of time because its competition is eliminated.

Oddly enough, if trees are thinned either for purposes of fire safety or the above mentioned "carbon release", the trees only grow back "explosively". So the very task of thinning seems counterproductive. Also, this mechanical task takes continued funding and staff, which state parks does not have at the present time.

Several proponents of thinning techniques during the interviews cited aesthetics as an important part of the management of redwoods. The clearing of the undergrowth and removal of smaller trees or suckers are purportedly for reasons of fire safety and aesthetics. When asked about thinning, one interviewee said:

The sense of aesthetics I get from an old growth forest, with fewer stems, trees that are larger and more widely spaced, it's just better, right? One of the things that it sets for us is a standard, and the standard is pre-European settlement conditions. Imagine what the forest looked like 300 years ago and that's what we're going for.

Another interviewee said:

We can see patches of old growth today and we can imagine what they look like 300 years ago. Generally, I think there would be a lot less vegetation on the forest 
floor. In general, what you are looking for are larger trees, more widely spaced, and an assortment of age classes and breaks in the canopy.

Yet another interviewee said:

The perfect park is, according to John Muir, "open and park like, where a man can ride a horse in any direction." In a properly managed forest, without any fires to suppress, a man can ride a horse in any direction. In my opinion forests right now need a lot of fires to clear out all the downed stuff.

One of the biggest challenges for environmental managers to understand and deal with currently is climate change. There is some research that indicates that climate change can decisively affect redwood ecology. While there is currently research being conducted to assess impacts of climate change on redwood forests, there are very few definitive markers that can be observed in the short term. Certain changes can be seen in the forest, but not much can be done directly by park managers to mitigate these changes immediately. For example, all interviewees talked of changes in coastal fog, which is essential to redwood forests and their propagation. With a reduction in coastal fog, there is widespread fear that redwood forests may be impacted, but there is no sure way to know how. As one interviewee put it:

There's a risk of climate change. You know that redwoods are dependent on fog and nobody knows what's really going to happen. We don't know if it's going to be hotter or colder and what exactly is going to happen to the weather patterns in 
these areas. Realistically, I'd like to say that the potential risks are unknown at this point...on a personal level I feel it's pretty much out of my hands.

Commercial logging in any protected area, including in a state park is not allowed by law. Using thinning or fire hazard logging as an excuse, timber companies have previously conducted logging operations in areas such as in the Eagle Lake Ranger District of Lassen National Park and the Giant Sequoia National Monument (Russell, 2010). Since the park staff depend on external research and studies for landscape management, the absence of clear guidelines on thinning protocols could spell disaster for redwood forests. Also, parties with ulterior motives could gain the upper hand with timber management. While many of the trees removed are small and conventionally of low commercial value, there is a market for smaller and smaller forest products (Russell, 2010). Many of the interviewees agreed that this could be a slippery slope, but they insisted that thinning was just a tool:

We glean information from other published works from researchers. We don't do any research ourselves. We try to incorporate the results into our future plans. There have been researchers who have done the research specifically on redwoods, on fire interval history, they've made maps, and there's enough data that you draw your own conclusions.

And: 
A lot of people thought the Healthy Forest Act was just a cover up for increased forest logging, and that's one way to look at it. The greater plan is getting the forest back to looking like it looked prior to logging. So if your goals are right, it's just a tool. You can tweak the tool around, and you can line up your goals with that of the department.

There has been a shift in thought processes as regards conservation from the time of conservationists like John Muir, and what is meant by conservation. As the data in these interviews show, opinions are divided when discussing the future conservation plans of redwood forests in Santa Cruz County. One interviewee said:

In the office, we joke about mentally logging as we're driving down Highway 9, of cutting down these trees. It's funny to have gone from a tree hugger and a tree lover to now being at a point where you now want to cut down these trees. We would like to do it, but we have no funding to do it.

With regards to forest management, one senior park employee said:

If a forestry company does the forestry management, it's usually a no cost contract...they get the value of some wood, depending on what they end up doing with it...no money exchanges hands...there is a contract and the contract says that the tree company will come in and thin our forest under " $\mathrm{X}$ " specifications or under the guidance of an ecologist. You will do this at zero cost and you are 
welcome to do whatever you want with the wood. They then take the wood and that gets milled or papered or whatever.

There were several concerns with this approach. California State Parks is a public entity and permitting forestry companies to go in and thin redwood forests sounded suspiciously close to permitting selective harvesting. The thinning was to be carried out under certain preset guidelines or under the guidance of an ecologist, but it was not indicated how these specifications were to be derived. The zero cost issue was another contentious matter. State parks devised this policy with the best intentions of not being able to profit off forest resources and products. However, from the above statement, it appeared that fact was disputable. This obvious loophole and its potential exploitation seemed counterintuitive to the spirit in which the no profit regulation was passed.

On a more dangerous scale is the very real existence of marijuana cultivation in the backcountry of redwood state parks. Until now, Mendocino and Humboldt counties were subject to this, but in recent years, rangers and ecologists have found several acres of marijuana cultivation in Santa Cruz County. Even more disturbing is the change in the type of cultivators.

One of the rangers offered the following comment:

This used to be a mom and pop kind of thing before, but now, it is carteldriven...the Mexican cartel. They bring in chemicals, which pollute the water; they dam the streams, which affect the fish; they cut natural vegetation and they 
are heavily armed. From parks in Santa Cruz, we take out more than 100,000 plants each year.

Another field staff member noted:

We have marijuana growers. They are armed people and they put toxics in the water. It used to be a more mom and pop kind of thing, where nobody cared, but now it's way more organized, and the environmental damage done in these cases is astounding. I visited one of the sites after the site was eradicated: they trench, they irrigate, and pour the toxins into the water and they have fecal matter from their waste. The amount of garbage is astounding, just to clean up the mess after, never mind the law enforcement, is a huge expense!

Park employees expressed distress over cartel driven marijuana cultivation for several reasons. The rangers were not really equipped to deal with heavily armed growers, and also because there is a dearth of rangers to patrol the backcountry and isolated regions of the parks. Park staff also described a situation where two tourists who were attacked when they accidentally came across the illegal marijuana at Castle Rock State Park. Thus, besides having armed cartels working inside the park boundaries, the state parks also had to be anxious about public safety.

Referring to impacts from errant tourists, a field staff employee remarked: 
Impacts from tourists is a constant struggle, with mountain bikers going off the trail and into the forest, they make new trails, they change the course of waterways, they make ramps, there's a great deal of environmental damage that goes on. There is soil compaction, the input of all kinds of different food, which leads to all kinds of impacts. The most obvious impact is the understory that can be destroyed. That will lead to increased runoff, leach into the creeks, so that will affect the ecology of the creeks. The one we focus most on is probably the marbled murrelet. They nest in the old growth, and the last five to six years we've spent a great deal of money in trying to mitigate those impacts.

With regard to visitor impacts, a new type of physical impacts had appeared in redwood parks. A field staff member responded:

Of late, we started to see that mountain bikers have started to put in their own trails. The mountain bikers want more trails, and we're not putting in trails quickly enough. I've seen redwood trees getting cut down. That's something I've seen in the last five to seven years that starting to increase.

\section{Management towards Sustainability.}

Local Community. Ecotourism projects can exist only if local communities are agreeable to it; if not, tourist experiences can suffer, and eventually lead to an unsuccessful tourism venture. For redwood parks in Santa Cruz, there exists phenomenal 
public support, which mostly shows in the way of volunteer and docent support. A state parks employee said:

We have community involvement on lots of different levels. At Henry Cowell alone, we have 80-90 volunteers, and that's a very large group. Big Basin also has a large number of volunteers; Portola is a little different because it's so remote. I'd say there's a lot of community involvement.

In contrast to these two parks, the Forest of Nisene Marks does not have too many volunteers or docents, only some part time seasonal employees from the community. However, a senior employee at Nisene Marks said that there was a different kind of local involvement:

I am in constant communication with recreational lists, especially the bicycling community, organizing races, and with neighbors who live around the park. There are several homes that are within the park property, and it's a constant challenge to work with neighboring landowners

Ecotourism. The central focus of ecotourism is environmental protection and conservation of natural resources in the area. The interviewees had varied opinions about the meaning of ecotourism as well as the potential for ecotourism in redwood parks of Santa Cruz. Opinions regarding the meaning of ecotourism were divided. One interviewee said: 
Ecotourism is enlightenment for people to get back in touch with nature, wilderness and environmental sites. So it is a way to get in touch with humanity in relation to the land. It is the best and foremost, a recharging of the spirit. The other is taking stewardship of the land, of the plants and animals that are now hedged in by parks, because they become reservations or refuges.

Another park employee said:

People pay money to visit someplace set aside because it has some unique natural or cultural feature of some kind. Set it aside, spend some money, and it will create enough revenue to pay for itself. That makes it economically worthwhile. It's trying to convince the private sector that it's worthwhile of this investment. In the end it's better for everyone economically.

Yet another employee said:

I think ecotourism would have to be a definition of tourism where the profits or benefits directly influence the sustainable management of the forest. Parks is not that. The money is not used directly to manage the park that people pay to come into the park. So there would have to be some kind of tie are people coming into view the redwoods and all that comes with it, and their willingness to pay for that.

While most interviewees had some notion as to what ecotourism was, only one interviewee's statement was similar to the generally accepted terms of ecotourism: 
Ecotourism is looking at how the spot is impacted, making sure that it's not impacted in a negative way, ensuring that the surrounding communities are well looked after, and it also depends on the area and what the passion of the people visiting it is. Hopefully that area and the communities around it will support that kind of atmosphere, with the right balance of getting people to visit and yet not misusing the environment and the local communities.

Surprisingly, the issue of whether the Santa Cruz redwoods could be considered a potential ecotourism destination drew the interviewees into two general points of view. The people who believed that the redwood forests had the potential to become an ecotourism destination and that tourists were already engaging in it, though it was not being marketed as such; and people who believed that the redwoods were just not "exotic" enough to become an ecotourism destination or that a pay as you use model was just not appropriate for state parks. One interviewee said, "Redwood trees have the potential to become an ecotourism attraction because unlike the gray whale, which is a magnificent creature, they are always there".

Another interviewee said:

In the United States, we are very lucky because we have a long tradition of parks and setting aside areas, Americans don't realize that the parks we have are in essence, ecotourism. The state is thinking of closing 70 parks, and we are saying 
that for every dollar you spend on state parks, we're giving back double that and more to the local economies. Ecotourism is just good business.

An interviewee from Nisene Marks said, "Because Nisene Marks is put aside with extreme protection, I would say yes, it can be an ecotourism destination, tourism is the top dollar figure for Santa Cruz County".

There were several people on the other end of the spectrum. One interviewee was of the opinion that redwood parks were just not exotic enough to warrant the label of an ecotourism destination:

I agree with the exotic aspect of ecotourism, it is off the beaten path, it has an expectation of danger and adventure... when I think of ecotourism, I think bugs, big cats, venomous spiders, the African savannah, Australian rainforests, and adventurous activities like parasailing or zip lining. It seems to me like it should have an element of danger even.

Another interviewee said:

I don't see why they couldn't be, but I struggle with the idea of turning these destinations and that experience into a for-profit sort of endeavor, which is kind of what's happening in slow motion right now. Our society is withholding the funds or has less money to spend on the parks, lands that are in public trusts for the public good. Whether you visit them or not they're still going to benefit you 
because they're there and because of what they provide. And we're going from this model to only the people who will visit them should pay for them and if you went to ecotourism that's the model we will be following.

An interviewee who was in two minds said:

Ecotourism is more like in the rainforest and stuff, not so much in the US. Ecotourism seems to me like you would have smaller organizations as opposed to a statewide organization. I somehow don't associate it with the developed world, but when I think about it, why wouldn't it be?

Research has shown that ecotourism isn't just about visiting places with natural beauty (Weaver, 2005); it is also about responsibility and stringent conservation. Echoing this, an interviewee said:

There's a group that's been writing letters to us, and threatening to sue us over how we are dealing with the marbled murrelet, an endangered bird. Sometimes, that's what is needed in order to precipitate a change in behavior. I see something like this being related to ecotourism, and given a sense of responsibility, and being at that point, a steward. But that would take a lot of work and improving our management style.

Education and Learning Opportunities. California State Parks primarily use brochures and interpretive panels to educate the visitors. Several different educational 
programs like campfire programs, junior rangers, and guided walks also add to the variety of educational programs offered. The exception to this was the Forest of Nisene Marks, which has almost no interpretive programs, unless someone requests it beforehand. Nisene Marks is more of a wilderness park that is mostly visited by the local communities. Over the last few years, docents and volunteers had to step in to fill many of these positions as staffing reduced each year. Many of the employees are seasonal and temporary. The interviewees agreed that much of the interpretive material comes out of Sacramento office, and that there is a severe review process for the final product.

A senior employee at Nisene Marks noted:

We have very little interpretive programs at Nisene Marks... we have a few docents who work out of Seacliff State beach, and on request we can arrange for a few interpretive programs and nature walks. In the summertime depending on how much money I have, there are one or two interpreters; they give nature programs in campgrounds, like campfires. There is also literature: there are brochures produced by Friends of Santa Cruz state parks, there is a free flier that we hand out with basic history. We also have interpretive panels with information on the park.

A senior staff member who worked in all four redwood state parks commented:

The archaeologists and academics within Parks publish our research in academic journals, but that's on a different level, the signage that you see for the public 
informs them, each park has a brochure or a booklet that's available for public use. We also have a docent program, and the docents go through training process, we have specialists who come in and teach them how to interact with the public.

Thus, it was apparent that docents increasingly played an indispensable role in the day to day functioning of the parks. They formed an important link between park management and tourists, especially as conduits of environmental messages to tourists.

In Portola, we have the marbled murrelet, and we educate visitors about how not to disturb them. We have display panel set up across the park, and we educate the public about how to protect the wildlife. We have brochures with condensed information, and also campfire programs. Junior ranger programs, hikes with interpreters, there are mountain lions fliers, which scare more than inform. There is a big dependence on information boards, as we have fewer staff every day.

Like the other parks, Portola State Park also had great dependence on interpretive panels and fliers. Certain fliers, like the mountain lion flyer, according to the interviewee were so outdated that they served to scare tourists more than educate them. Fliers also had a chance of just adding to the trash to be left behind in the parks.

One of the senior docent interviewees had an interesting perspective on how tourists must be educated and given information in parks: 
Information is usually through printed matter, but most importantly I think it's through the interpretive programs, especially to the kids, because they are our future. Personally I think the most important is that school outreach. I think it's important to learn about the value of natural resources and how to protect them. It's a process, first and you learn about them and then you learn to value and respect them. That's when you really appreciate it and support it. I think this interaction is a very important part of learning, and just reading a brochure doesn't give you that. I think person-to-person interaction is the best education with a give and get.

Oddly, these suggestions were voiced only by the docent interviewee, and not by the employees of the state parks. This approach is supported in literature by Ham and Weiler (2003) and Orams (1996), among others. It has been argued that a personal form of communication is the most effective way of giving information, especially in tourism destinations (Urias, 2009). Depending on the modes of personal communication, tourists can be inspired to adopt new ways of engaging in environmental stewardship.

Tourist Expectations. The major visitor impacts on the redwood forests comes in the form of vandalism, feeding birds and animals in the park, tree carvings, poaching of animals and stealing of redwood burls and trees. Most visitors also want to take pictures of the big redwood trees while standing on their roots, which can harm the taproot system. Visitor characteristics as described by the interviewees ranged from conservation oriented 
tourists to the see one tree and you've seen them all oriented tourists. According to one state park employee:

Everybody wants to take pictures in front of the old huge trees, but the irony is that you can never get a complete picture of one of those huge trees...

Another interviewee explained:

There are all these people who just want to walk around the redwood loop, and this is sad for me. We get a lot of international visitors and that kind of validates my appreciation for the redwoods. When I lead a group of adults, I have to be very careful about what I say because I can hear comments about we did not come up here to listen to a lecture.

It was important to analyze how material delivered to the tourists achieved its objective and did not annoy them instead. As one of the elements of ecotourism, it is essential that agencies in charge of the destinations deliver effective interpretation, ensuring that tourists left with more information and with a spirit of enlightenment (Boon, Fluker \& Wilson, 2008; Orams, 1996; Ham \& Weiler, 2003).

Education in the context of ecotourism has potential to facilitate a greater chance of fostering stewardship if information is disseminated in more than one way transfer of information. It must involve an explanation and a stimulation and thought provoking delivery that will help in transforming the tourist. This is particularly challenging, and is 
more so when destinations depend on non-personal techniques such as signage, panels, and brochures rather than face to face interpretation. This is a key challenge and a key goal of ecotourism at the same time (Urias, 2009). When successful, it can be the most important contribution of ecotourism: exposing the tourist to the need to protect natural resources and instilling in them a sense of environmental stewardship and accountability.

While this was not a specific question that was asked during the interviews, an interesting pattern concerning Portola State Park emerged. Several interviewees described the unique standing of Portola amongst the redwood parks in Santa Cruz.

One employee at Portola remarked:

To go to Portola, you have to want to go to Portola. It's a destination park. People tend to be much more respectful in destination parks. People don't happen upon Portola. The other parks have wood poaching, but not really at Portola because it's well protected at the bottom of the basin. I have found marijuana plantations in other parks, but not really in Portola.

Another interviewee said:

Portola is a very remote location, and it gets used a lot less than the other destinations. It's like Big Basin on a smaller scale, and the old growth is all magnificent. There are very few people out there, and the ones that do come there are determined to come there for that very experience. 
The interviews provided an overwhelming amount of data that not only answered the study questions, but also provided additional information that was not previously considered. The two primary results from the interviews revealed the importance of docents in the resilience and functioning of California State Parks. Portola State Park also materialized as an unexpected result as a potential destination for initiating ecotourism development in Santa Cruz state parks.

\section{Visitor Survey Results}

Visitor surveys were collected from 150 visitors at Big Basin Redwoods State Park. Tourists form an important stakeholder cornerstone in tourism research and in ecotourism research in particular. The survey consisted of 14 multiple-choice questions, and one open-ended question. The survey was designed in a manner to aid the application of simple descriptive statistics and complement the qualitative interviews from park staff. The survey was designed to elicit opinions from tourists about ecotourism in redwoods and their willingness to pay for visits and conservation of the forests. Demographic data of visitors was also collected. One question covered tourist motivations for visiting a redwood forest and their expectations from their visit.

The results of the tourist surveys indicated that the largest percentage of tourists was a younger population, a majority of the tourists were from California, and that a large number of the tourists had visited redwood parks before. Most of the visitors visited redwood parks for hiking and spiritual rejuvenation. Visitors were not willing to pay 
higher entrance fees to state parks, but a large percentage of tourists were willing to pay towards conservation efforts at state parks.

A large majority of the surveyed visitors were of the opinion that redwood forests were at risk from timber extraction, thus affecting wildlife habitat. A simple $t$ test was run to calculate for significance between the means of visitors who had visited redwood parks previously and also considered these parks to be at risk from timber extraction. The result indicated that people who had visited redwood forests previously were more likely to consider redwood parks at risk from logging. Visitors were also asked if they considered ecotourism a conservation strategy for redwood parks, and a majority of visitors indicated that it was a viable option. However, when a $t$ test was run to calculate for significance, there was no significant difference indicated between previous redwood park visits and considering ecotourism a feasible conservation strategy.

Demographics: Age and Location. To ensure that no children participated in the survey, a visual determination was made to exclude visitors below 18 years of age. One third of the visitors surveyed, or 50 people, were between the ages of 25 and 35 years, followed by approximately $30 \%$ of the visitors between the ages of 46 and 55 years. The researcher observed that many of the younger population were with small children, and some of these visitors noted that they liked visiting redwood parks with their young children. Two people of the 150 surveyed were below the age of 25 . 


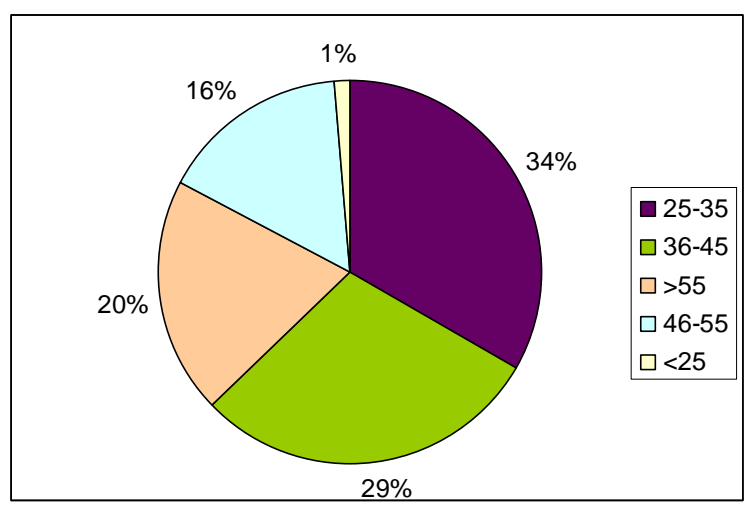

Figure 7. Age distribution, in years, of tourists surveyed.

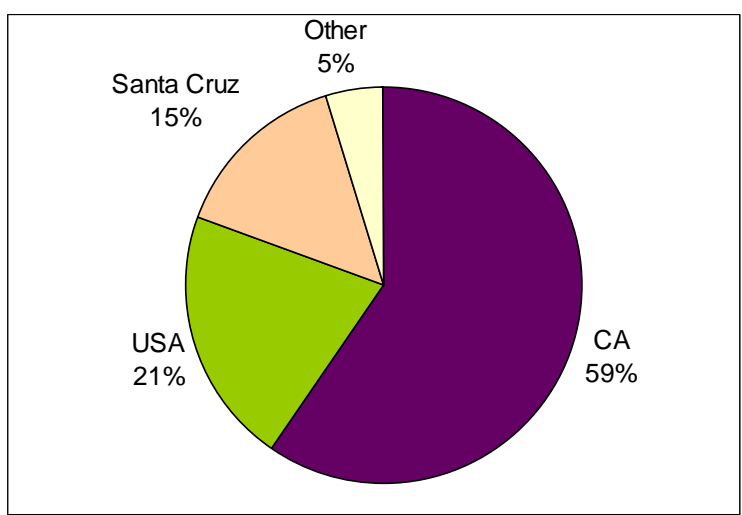

Figure 8. Origin of tourists. This figure shows the origin of surveyed tourists.

Of the tourists surveyed, $59 \%$ or 89 people of the visitors were from California. This was followed by 21 of the visitors who were from other parts of the United States. Locals from Santa Cruz County accounted for $15 \%$ of the tourists.

Big Basin Redwoods State Park is considered the representative redwood park in Santa Cruz, and $5 \%$ of the surveyed visitors were foreign tourists. Several people who were asked to answer the survey declined to respond. 
Frequency of Visits. Over $85 \%$ of the surveyed population had visited redwood parks or redwood forests previously, and $60 \%$ of the tourists had visited a redwood forest more than ten times. Of the visitors surveyed, $21 \%$ had visited redwood forests fewer than five times. More than $43 \%$ of the tourists who had visited redwood forests before visited redwood forests regularly and more than twice a year. About $31 \%$ of the repeat tourists visited redwood forests once a year. Approximately $64 \%$ of the visitors surveyed had visited Big Basin Redwoods State Park before. Of the people who had visited Big Basin before, $6 \%$ had visited the park more than 10 times.

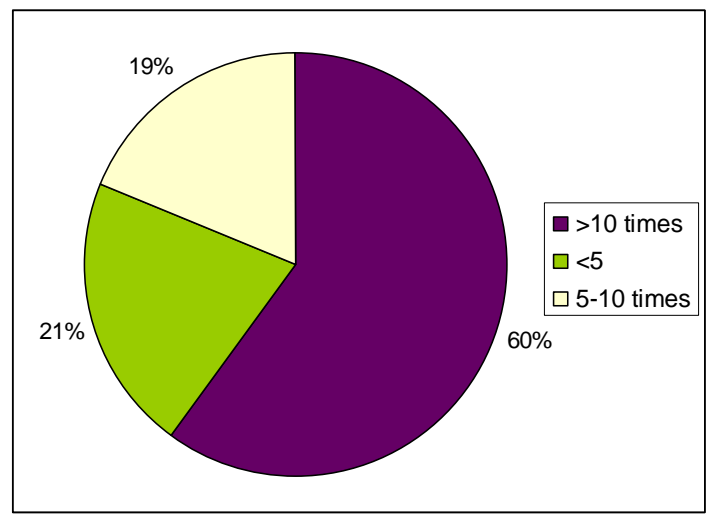

Figure 9. Frequency of tourist visits to redwood forests. This figure shows the percentage of tourists who had visited redwood forests previously.

Motivation for Visit. Of the tourists surveyed, 125 tourists or $83 \%$ visited redwood forests for hiking. Of the 125 tourists, 41 tourists visited redwoods forests with other motivations such as camping, being out in fresh air, camping, and spending time with family and friends. Of the 150 tourists surveyed, 42 visited the forest for spiritual rejuvenation. No tourists were visiting redwood forests for hunting and fishing. None 
were visiting Big Basin Redwoods State Park for bicycling, but it should be noted that this is not a park that is popular for bicycling. The result would probably have been different if the survey was conducted at Nisene Marks State Park, where bicycling is very popular.

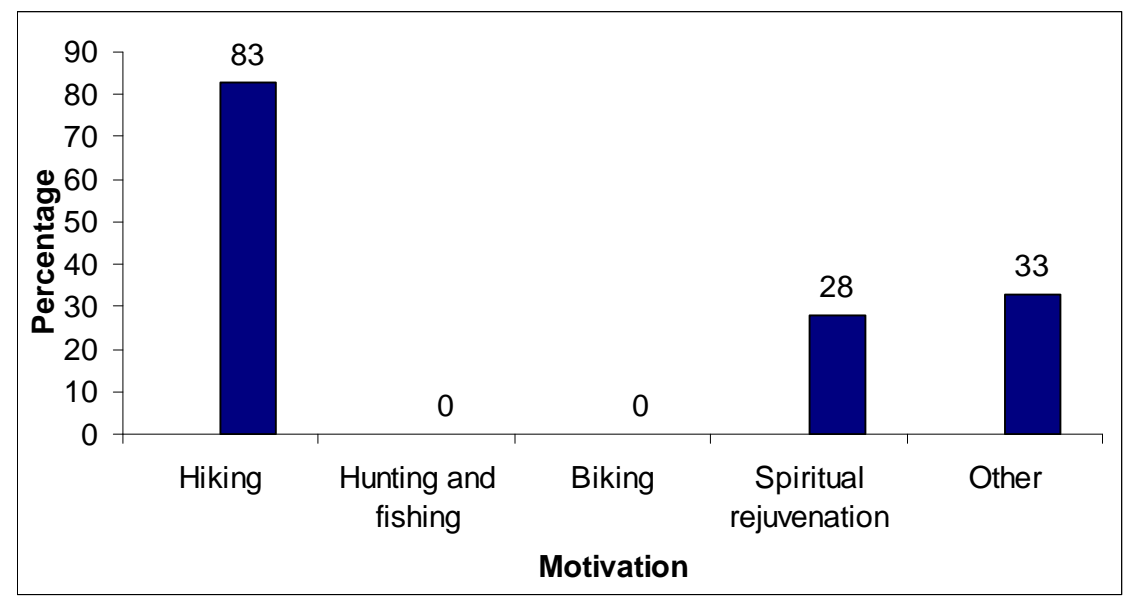

Figure 10. Tourist motivations to visit a redwood forest.

Redwood Forests at Risk from Timber Extraction. The surveyed visitors were asked to agree or disagree on a Likert scale for assessing their opinions on risks from timber extraction to redwood forests. On a five point scale, visitors chose ranks between "strongly agree" and "strongly disagree". "Strongly agree" was given a rank of one and "strongly disagree" was given a rank of five. Of the 150 visitors who were surveyed, $74 \%$ agreed that redwood forests were at risk from timber extraction and logging, thereby threatening wildlife and habitat. Of the surveyed visitors, 5\% disagreed that redwood forests were at risk from timber harvesting. Almost $21 \%$ of the respondents neither agreed nor disagreed. 
Four $t$ tests conducted to test for significance between the means showed only one significant result. The "yes/no" questions, "have you been to a redwood park before?" and "have you visited this park before?" were tested individually against "redwood forests are at risk from timber extraction and logging, threatening wildlife habitat" and "ecotourism can help to conserve redwood forests." Visitors who had been to a redwood park before $(M=1.65)$ were not likely to consider ecotourism as helpful in conservation of redwood parks any more than tourists who had not visited $(M=1.59)$ redwood parks before $(p=.35)$.

Testing for significance between the means of visitors who had visited Big Basin Redwoods State Park previously $(M=1.67)$ and visitors who had not visited this park before $(M=1.59)$ indicated a non significant result $(p=.26)$. Thus, it could be inferred that whether the surveyed tourists had visited Big Basin or not, it had no bearing on their opinion of redwood forests being at risk from timber extraction.

Visitors who had been to Big Basin Redwoods State Park previously $(M=1.88)$ showed no likelihood of considering ecotourism as helpful in conserving redwood forests more than visitors who had never visited Big Basin before $(M=1.89)$. The $t$ test between the means of the two groups indicated a non significant result $(p=.48)$.

When the means of people who indicated "yes" $(M=1.82)$ were tested was tested against the means of people who indicated "no" $(M=2.31)$, there was a significant difference $(p=.009)$, indicating that people who had visited redwood parks before, were more likely to agree that the forests were at risk from timber extraction and logging, thus 
threatening wildlife. While any interpretation of statistical results must be made cautiously, one can safely infer that people, who had visited redwood parks before, were more aware of the risks presented by timber extraction and logging than new visitors to redwood parks.

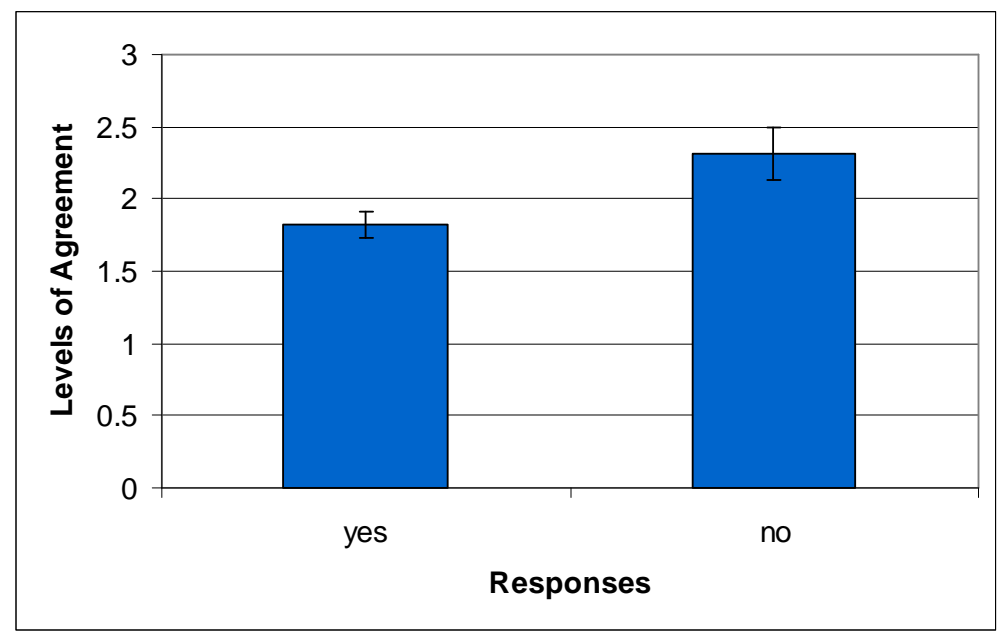

Figure 11. Awareness of risks to redwood forests. This figure shows the difference in means between tourists who had visited redwood parks previously and tourists who had not visited redwood parks previously.

Ecotourism as a Conservation Tool. On a Likert scale, the respondents were asked to choose between "strongly agree" and "strongly disagree" on a statement whether they thought ecotourism could help conserve redwood forests. Of the surveyed respondents, 90\% agreed with using ecotourism as a conservation tool. Exactly 13 respondents neither agreed nor disagreed, and two respondents disagreed. 
Willingness to Pay: Visitation and Conservation. When asked about willingness to pay to visit, $36 \%$ of the visitors were willing to pay $\$ 5-\$ 10$ to visit a redwood forest, $22 \%$ were willing to pay $\$ 16-20$, and $13 \%$ were willing to pay more than $\$ 20$. The largest segment of the surveyed population was willing to pay between $\$ 5-\$ 10$ to visit a redwood forest.

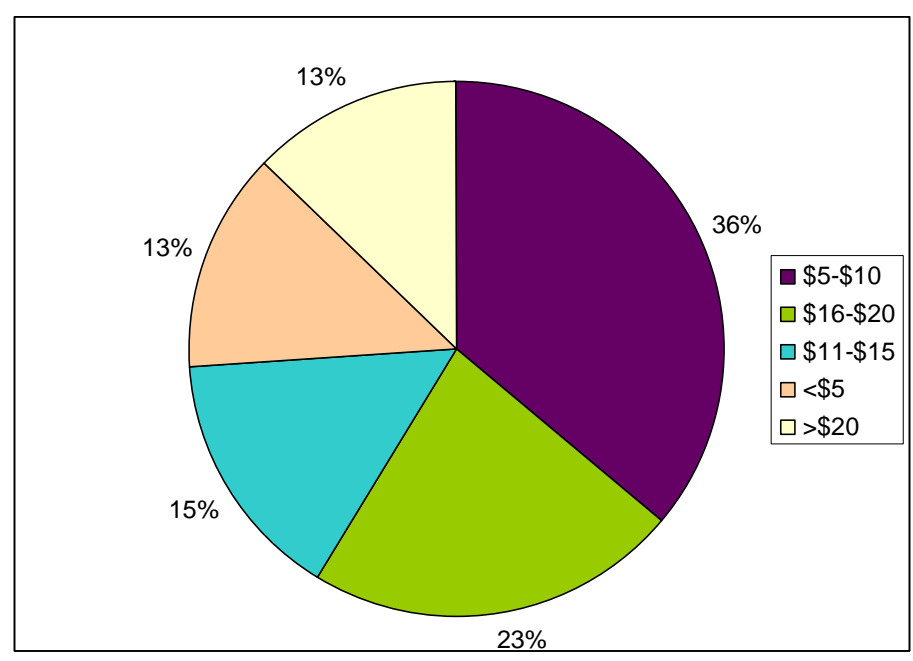

Figure 12. Willingness to pay to enter a redwood state park.

Interestingly, many of the respondents $(47 \%)$ of the same survey population were willing to pay more than $\$ 20$ a year towards conservation of redwood forests. 


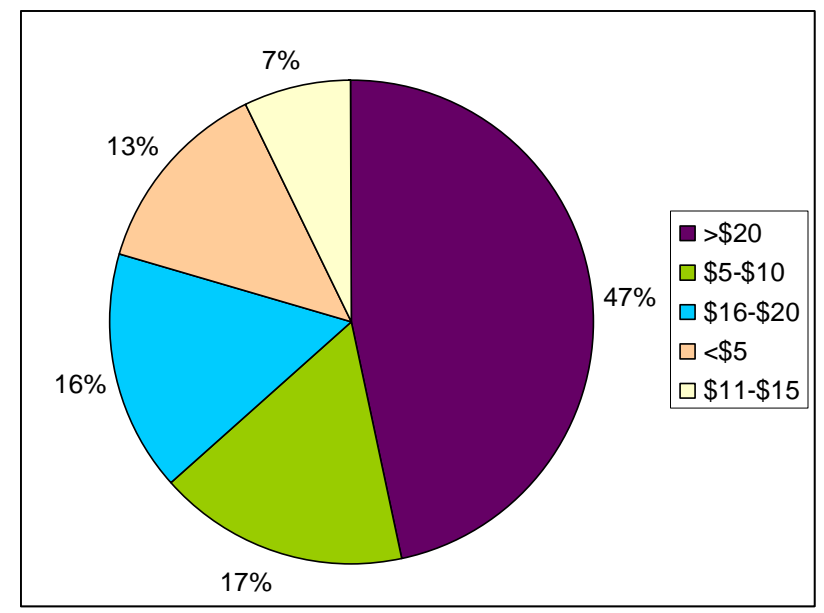

Figure 13. Willingness to pay towards the conservation of redwood forests and parks.

Of the tourists surveyed, $13 \%$ of the respondents were willing to pay less than $\$ 5$, and some of them explicitly were not willing to pay anything at all. The respondents willing to pay more than $\$ 20$ were willing to pay between $\$ 25$ and $\$ 100$, with two people willing to pay $\$ 100$.

Fee/Donation Allocation. Of the surveyed tourists, 135 respondents (90\%) indicated that they would like their fee or donation to be spent towards conservation. A similar percentage of people indicated that they would also like their fee to be spent towards maintenance of tourist facilities. Most respondents said they would like their donations to be allocated towards more education programs in the parks. Of the respondents, 28 respondents (19\%) were in favor of their fee or donation being spent towards timber management or harvesting. Considering responses to the previous question of whether redwood forests were at risk from timber extraction, a number of people agreed strongly. 
Tourist Expectation in a Redwood Forest. Of the surveyed tourists, 128 (85\%) respondents expected a tranquil environment when they visited a redwood forest, with about $80 \%$ of the tourists also expecting to see big trees. Approximately $60 \%$ of the respondents expected to see a lush forest. None wanted shopping facilities.

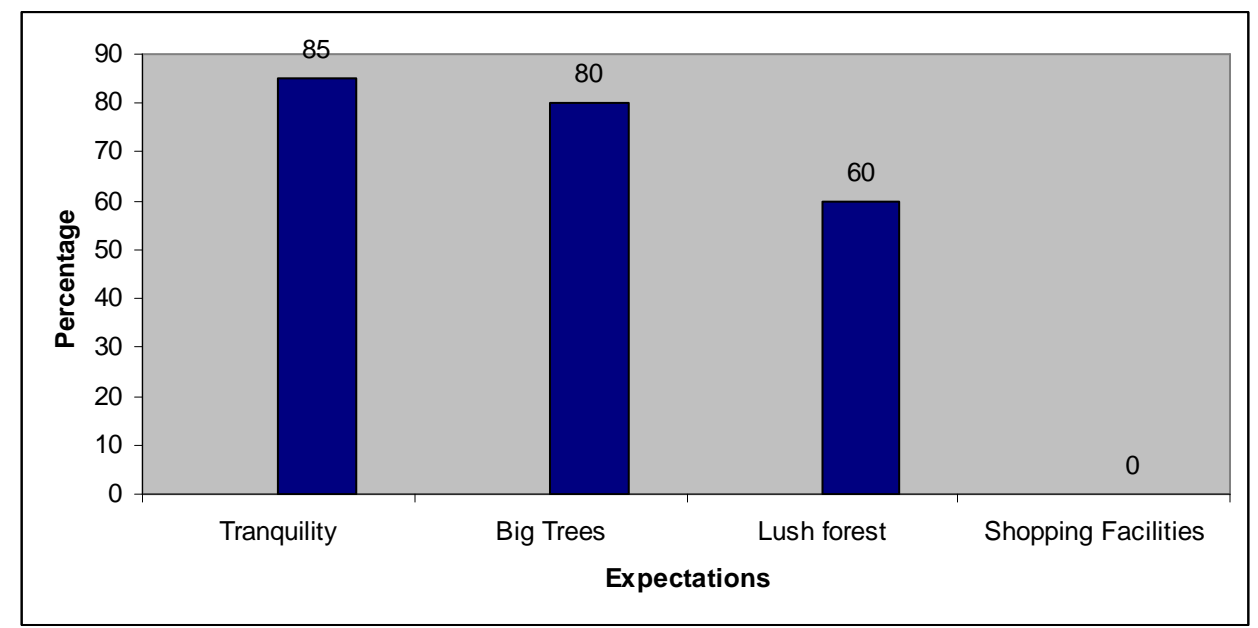

Figure 14. Tourist expectations in a redwood park. The figure shows that tourists expected to see a tranquil park, big trees, and a lush forest when visiting a redwood park.

Open-Ended Questions. The open-ended question asked respondents to give their opinions on conservation and protection of redwoods at state parks. One dominant theme that appeared in these responses (where people chose to write them) was a request to increase education programs for children and adults. Another theme that appeared in the open ended question was a request for more conservation programs and information from the state parks. 


\section{Discussion}

This study assessed the potential of developing ecotourism as a conservation tool in redwood forests of Santa Cruz. The four key redwood parks in Santa Cruz are Big Basin, Henry Cowell, Nisene Marks, and Portola Redwoods State Parks. These four parks together formed the study area. Conservation of fragile habitats is increasingly acknowledged as an issue that requires environmental and socio-cultural concerns to be discussed both in relation to local communities and resource managers. Therefore, this study was carried out by targeting both local and park management populations. The two populations interviewed were state park staff at all four parks (including employees and docents) and tourists at Big Basin Redwoods State Park.

If an integrated development and conservation project is to succeed, all stakeholders must receive positive benefits from the ecotourism project implementation. If this relationship is symbiotic, the project is more likely to succeed (Parker \& Khare, 2006).

For this reason, the current study interviewed state park employees to gain an understanding of the organization's management and visitor policies as well as the perspective towards implementing ecotourism in redwood parks. Tourists were interviewed at Big Basin Redwoods State Park to gain an understanding of visitor opinions toward conservation, redwood park management, and ecotourism. 


\section{Nature-Based Component}

The relationship between resource management and tourism was less than satisfactory when analyzing the fact that resource management protocols seemed to be designed in more of a lenient manner than a stringent manner when dealing with an endangered ecosystem. Tourists, in general, did not seem to be aware of any implications, and as such, tourist facilities did not seem affected. One of the central themes of ecotourism is the goal towards a positive gain of natural resources, and the implications of current resource management policies at California State Parks seem confused. The objectives of thinning out smaller trees to achieve release and eventually increase biomass to encourage carbon sequestration seemed counterproductive with fire safety concerns. The future plans of mechanical thinning, contingent on available funding, indicated an experimental approach in an endangered ecosystem that deserved a more scientific and unbiased analysis of the results of such actions.

The notion of aesthetics also played an important role in the management of redwood parks. Many of the state park employees were of the opinion that redwood forests looked neat and better with fewer, bigger trees, and wider spaces. One staff member suggested that the park should have spaces wide enough for a man on a horse to ride through in any direction, just as John Muir stated a century ago. Since the time of John Muir, policies and ideas of preservation and conservation have changed. More importantly, objective scientific analysis rather than aesthetics should form a basis for resource management. 
These decisions should be based in unbiased, scientific studies that protect redwood ecosystems, rather than just subjective aesthetics.

Where tourists were concerned, the state park employees maintained tourist facilities even in the face of severe budget cuts. Even with docents to assist in many tasks, the staff was stretched to work beyond their regular duties. Tourists expected to see big trees and desired a tranquil environment while in a lush forest. Current marketing and advertising efforts tend to focus on the idea of "big redwood trees", and not an entire redwood ecosystem. Visitor education is also focused towards larger sized trees and not towards the entire forest. Tourism, even ecotourism in many instances, can focus on charismatic megaflora, but in an ideal ecotourism setting, resource managers must foster a healthy ecosystem and tourists must be educated as such.

\section{Learning and Education Opportunities}

Overall, the redwood state parks in Santa Cruz provided some opportunities for education and learning in the form of interpretive programs, but these interpretive programs were not available in all four parks. Big Basin Redwoods State Park and Henry Cowell Redwoods State Park had the most extensive set of interpretive programs for tourists. The programs were typically offered through the summer months and part of early fall and late spring months. The Forest of Nisene Marks and Portola Redwoods State Park did not have any educative and interpretive programs unless specifically requested beforehand, and that was dependent on available funding. 
The tourist survey which was conducted at Big Basin Redwoods State Park indicated that tourists desired more educational programs for adults and children alike, along with in-depth information and content. Some of the tourists who specified what they would like to see in the interpretive programs stated they would like more information on climate change and redwood forests, more awareness about human impacts on redwood forests, and information on restoration of damaged areas. The most common suggestion for the conservation of redwood forests was an increase in the number and quality of educational programs. One respondent suggested showing short films of endangered species in redwood forests.

During the interviews, some interesting and overlapping ideas between tourist suggestions and park employees appeared. The park managers had been considering showing a short film on the marbled murrelet in redwood forests, and there was a very similar suggestion that was made by a tourist as mentioned above. One of the docent interviewees had strong suggestions for a more informative and appealing visitor center at Big Basin Redwoods State Park, and this was a view endorsed by many visitors.

In all four parks, interpretive panels at the entrance and or on hiking trails were present. By the admission of most park employees, these forms of signage were old and in definite need of repair and updating. Brochures were also available, but were only given to tourists on request, because most of the brochures tended to be discarded as trash or as litter. One interviewee remarked that one of the brochures on mountain lions frightened more than informed. Educating the tourist is an extremely important priority 
of state parks and one of the primary goals of ecotourism; hence, it is essential to design informational material accordingly and appropriately.

Other educative programs such as campfire programs, junior ranger programs, junior junior ranger programs, and docent-led or ranger-led hikes were offered throughout the summer in Big Basin and Henry Cowell Redwoods State Parks, but these were rare in both Portola and Nisene Marks Redwoods State Parks. Visitation numbers and funding were both significantly lower in the latter parks, but if either or both parks are to be considered as potential ecotourism destinations, it is imperative to have powerful and appealing interpretive programs.

Most of the interpretive programs were supported by docents and volunteers, though there were some programs that were managed by paid employees. It showed to the elastic and supportive nature of the community of docents of the redwood parks, that in a time of financial and staffing difficulty, the docents filled in many essential gaps, especially in interpretive programs. This was one of the key findings of the study. While volunteers and docents play an important part in many parks, the number of docents who had been with the California State Parks at the redwood parks for a number of years was surprisingly large. A unique relationship had formed where not only were the parks supporting the local communities, but the local communities were sustaining the parks. 


\section{Management towards Sustainability}

It was evident from the interviews and observations during the survey administration that docents and volunteers played an important role in visitor services at all four redwood state parks. With stringent budget and staffing cuts in the parks' management budget, docents, many from neighboring communities, had stepped in to fill the gaps, especially in visitor services such as interpretation and educative programs. Docents led hikes, gave campfire programs, and welcomed tourists into visitor centers. They were also involved in trail maintenance and cleaning.

The involvement of docents was greater at Big Basin and Henry Cowell Redwoods State Parks than at Portola and Nisene Marks Redwoods State Parks. This is not to say that there was no local involvement at the latter parks, but it was on a smaller scale than at the other two parks. The interviewees all discussed the importance of the docents from the local communities.

Some of the interviewees talked of the dependence of local communities on the state parks and the tourists. Small mountain towns such as Ben Lomond and Boulder Creek were dependent on tourism to Big Basin Redwoods State Park, and all the interviewees were keenly aware of the fact. The Forest of Nisene Marks State Park, according to the interviewee from the park, had very strong support from the community, who viewed the park as their local park, or as their hidden gem. While some docents worked there in the summer, the park users were locals who visited the park for hiking, running, and mountain bicycling. 
The other facet of local community involvement was that of non-profit organizations, which were involved in activities ranging from trail maintenance to volunteering to fundraising for the management of the parks. At Nisene Marks, local non-profit organizations supplied brochures for the park. At Henry Cowell, another non-profit organization, the Mountain Parks Foundation, funded a large part of the interpretive program. The significantly larger non-profit organizations such as Save the Redwoods League and the Sempervirens Fund were also very involved in the larger scheme of things such as buying and donating tracts of redwood lands on the fringes of the parks. When Portola Redwoods State Park was threatened with closure due to budget cuts, Save the Redwoods League, along with the Peninsula Open Space Trust, raised \$100,000 to keep the park open.

Managing an entire ecosystem for environmental sustainability involves many complex systems and requires a delicate balance to ensure ecosystem health. There is, however, an expectation that resource managers base their decisions on unbiased scientific data.

Tourists who answered the surveys overwhelmingly supported the idea of ecotourism in redwood parks. State park employees were, however, mixed and cautious in their responses to the idea of implementing ecotourism in California, and a country such as the United States. The issue seemed related to preconceived ideas of what ecotourism should be and the perceived location in developing countries. 


\section{Conclusions}

Although a single accepted definition of ecotourism is yet to be coined, most definitions include responsible travel to natural places, a positive contribution to the local communities (Dubin, 2008), and instilling in the tourists an understanding of the significance of conservation (Goodwin, 1996). Research shows that an actual experience has greater impact than just reading about it, along with adding different perspective while or after experiencing it (Cornell, 1979; Miles, 1991). For example, seeing a deforested area has a different and greater impact than just reading about it (Dubin, 2008).

Research has shown that ecotourism can be considered a segment of specialized tourism appropriate to a developed country like the United States (Bryan, 2008). Bryan discusses the necessity of widening the conventional definition of ecotourism so as to include developed first world countries as existing or potential ecotourism destinations. The study also discusses a sustainable facility, local community involvement, and appropriate educational activities at the destination as being essential to an ecotourism venture. The same study emphasizes the need for a responsible travel marketing strategy to convince all stakeholders within the ecotourism project of the possibility of success.

Until now, ecotourism has been considered a developing country concept, especially where climates are less extreme, the labor is less expensive, and the seasons are longer than in the developed world (Bryan, 2008). The redwood forests of California could be considered for ecotourism development as it fulfills many of the essential factors necessary for an ecotourism destination. While labor is decidedly not inexpensive in the 
study area, this factor does not hinder the potentialities of ecotourism to the extent that the other factors do.

The state park employees' reactions to being asked why ecotourism could not be an option in redwood parks included bewilderment. Some interviewees opined that when people visited state parks, it was automatically classified as ecotourism, but that it just had not been marketed that way. Most interviewees were of the opinion that ecotourism was not the best option for redwood parks because these forests lacked exoticness, wild animals, and a sense of adventure or danger. Yet, no interviewee could explain why it was not possible to develop ecotourism in the redwood parks of Santa Cruz. However, the interviews were conducted with locals who had lived in the area for most of their lives, thus giving them a sense of redwoods being ordinary. A visiting tourist could be visually and emotionally struck by the exotic redwoods. This was confirmed by all the interviewees who admitted that most tourists were wonderstruck by the majesty of coast redwoods.

Monitoring the biophysical impacts of tourists in parks is essential. Due to a lack of staff and funding, there was not much quantitative monitoring of impacts in the redwood state parks in Santa Cruz. To quantify impacts, or to assess what is in the best interests of the protected area, it is essential to have baseline data to compare against, but this data is rarely available. Giongo et al. (1993) studied 319 parks across the world, and concluded that fewer than $50 \%$ of the parks in developed countries had any impact monitoring at all. However, monitoring is essential for any ecotourism project because if there is no 
monitoring, there is no way of knowing if any progress has been made towards the set objectives or goals (Eagles et al., 2002).

There is little doubt that there are structural challenges associated with developing responsible ecotourism in a consumer oriented country like the United States, but it is important to realize that ecotourism is not a concept based on geography alone, but a concept based on managing the environmental impacts of such ventures (Pearce \& Ocampo-Raeder, 2008).

Landscapes have been altered ever since humans have been present on the planet. Beginning with modernized agricultural systems, the changes to natural ecosystems have been severe and drastic. On the one hand, agricultural changes have brought about destruction of natural systems, and, on the other hand, have brought food production to the highest levels ever known. With increasing pressure on natural systems, development and conservation are at a collision juncture at this time.

Several conservationists believe that natural systems do best when left to themselves and that these forests do not need heavy manipulation by people in order to thrive. It is also true that many times when public agencies and non-profit organizations are experimenting with fragile ecosystems, presumably with the best intentions, some ecosystems are highly endangered, and managing them needs to be based on objective scientific and triangulated methods. This also brings into question the role of vested interest groups, which can have considerable influence on management and environmental policy on public lands like redwood state parks. 
The coast redwoods are amongst the most endangered ecosystems on the planet (http://www.sempervirens.org/redwoods.php); thus, the objective for state parks should be to protect the whole ecosystem as opposed to just the big trees for the sake of aesthetics or misguided notions of old growth carbon sequestration. There is literature available that shows thinning to be a potentially political strategy for timber harvesting rather than just a management tool. Another issue that stems from experimenting in fragile ecosystems is that many changes may become irreversible and this in turn, can be disastrous for the ecosystem.

The ability of redwoods to sprout and grow back has led to the misconception that redwood forests can grow back to their original form even when they have been cut (Noss, 2000). Redwood forests are complicated ecosystems and a result of many evolutionary processes, which cannot be brought back to their original glory in a few decades.

It is true that green washed tourism projects under the title of ecotourism can exist even in a working forest that is heavily manipulated. However, if redwood parks in Santa Cruz are to become real ecotourism destinations, it is essential that clear objectives of environmental sustainability and impact management direct the process.

The value of nature cannot be monetized (McCauley, 2006). Nature is not only about resources and productivity. The most important part of nature is the fact that it is there and that in itself warrants protection of a unique, complicated network of life. A senior ecologist at state parks remarked that as a society, humans have all lost an integral 
connection to nature and thus the inherent need to protect nature in its entirety. It is beyond the scope of this study to explore this issue, but it is worth mentioning that one of the tenets of ecotourism is to foster a greater understanding of the global perspective of the impacts of human interfaces with nature. A docent who was also an interviewee had been visiting Big Basin Redwoods State Park for the last several decades. According to the interviewee, there is a sense of calm and rejuvenation that can be got from walking through the redwoods. He also remarked that not many people seemed to feel that connection.

During the course of the interview, many of the state park employees expressed their concern about the way the organization was being managed, including fiscal policies and the dire situation of state funding. Several employees were working off external grants that were given to them for specific projects, but most employees were extremely concerned about their jobs on a day to day basis. Due to severe cutbacks in personnel, all employees were overworked and forced to handle many more parks than usual. This led to low morale and a sense of job insecurity, which affected employee motivation and their ability to perform their job.

If fragile ecosystems and landscapes are exposed to large scale tourism that has its foundations in corporate and capitalist ventures, responsible travel can become a green washing campaign for extractive activities. It is not a question of whether responsible ecotourism can be achieved, but according to Bryan (2008), it must be achieved in order to lead towards a more sustainable environmental situation. 
It is important to realize that ecotourism is not like a glove that fits all. As different ecosystems require different systems of management, so does ecotourism require different management in different destinations. Most research in the area of ecotourism has dealt with ecotourism development in developing countries. The three elements of ecotourism namely, nature-based, education opportunities, and sustainability must have a positive balance, however small (Pearce \& Ocampo-Raeder, 2008). These elements can also be represented in different proportions in different destinations, but they need not be developed together and equally. The idea behind the process of developing an ecotourism destination is that it does not change all negative impacts, but adds to the education, inspiration and sustainability of the destination, communities, and travelers alike.

With lofty goals, ecotourism must be able to present a positive result if it is to be considered truly environmentally friendly. It must be able deliver on some key aspects to convince all skeptics (Durham, 2008). Unlike many forms of commercial activity which tend to be extractive in nature, ecotourism offers an opportunity to replenish and empower destinations. An elemental list of questions (Fennell \& Dowling, 2003) can help policy makers make initial strides:

- Who needs to be involved in ecotourism policy development?

- Which are the principles we want to guide our development of ecotourism?

- Why will individuals and organizations want to be involved in ecotourism?

- Where do we want ecotourism to take place? 
- What kind of activities should make up ecotourism?

- What are the intended outcomes we want from ecotourism and to whom or to what should they accrue?

\section{Recommendations}

A study by the Santa Cruz County Conference and Visitors Council shows that only $18 \%$ of visitors to Santa Cruz visit for the redwoods. It is recommended that, along with other destinations, redwood forests be promoted as an ecotourism destination once the appropriate policies are in place. A stronger relationship should be built with local communities that are dependent on tourist traffic.

Portola Redwoods State Park has been ignored on the management list for the last two decades, with no thinning, clearing, or burns. One interviewee referred to Portola as the "ugly stepchild of Big Basin" because this park has not been maintained, thinned, or managed over the last few decades. Due to this very lack of maintenance and human disturbance, Portola would be the ideal destination for an initial potential ecotourism venture.

The interpretation programs at the Santa Cruz redwood state parks can present visitors with more substantial information about the coast redwoods. It is essential that strong attempts be made to change attitudes and behaviors of visitors to encourage greater environmental stewardship. 


\section{References}

Altman, J., \& Finlayson, J. (2003). Aborigines, tourism and sustainable development. Journal of Tourism Studies, 14(1), 78-91.

Aylward, B., \& Freedman, S. (1992). Ecotourism. Global Biodiversity, 413-415. doi: 10.1007/BF00051777

Ballantyne, R., Packer, J., \& Hughes, K. (2009). Tourists' support for conservation messages and sustainable management practices in wildlife tourism experiences. Tourism Management, 30(5), 658-664. doi:10.1016/j.tourman.2008.11.003

Barbour, M., Lydon, S., Borchert, M., Popper, M., Whitworth, V., \& Evarts, J. (2001). Coast Redwood: A Natural and Cultural History (2nd ed.). Los Olivos, CA: Cachuma Press.

Barnes, J., Schier, C., \& van Hooy, G. (1997). Tourists' willingness to pay for wildlife viewing and wildlife conservation in Namibia. Desert Research Foundation of Namibia. Retrieved from http://www.met.gov.na/publications/research/rdp_0015.pdf

Bjork, P. (2000). Ecotourism from a conceptual perspective, an extended definition of a unique tourism form. International Journal of Tourism Research, 2, 189-202. doi: 10.1002/(SICI)1522-1970(200005/06)2:3<189::AID-JTR195>3.0.CO;2-T

Blamey, R. K. (2001). Principles of ecotourism. In D. B. Weaver (Ed.), The encyclopedia of ecotourism (pp. 5-22). New York, NY: CABI Publishing. doi: $10.1079 / 9780851993683.0005$

Bleher, B., Uster, D., \& Bergdorf, T. (2006). Assessment of threat status and management effectiveness in Kakamega Forest, Kenya. Biodiversity and Conservation 15, 1159-1177. doi: 10.1007/978-1-4020-5208-8_7

Boo, E. (1990). Ecotourism: The potentials and pitfalls: Country case studies. Washington, DC: World Wildlife Fund.

Boo, E., \& Lindberg, K. (1993). Ecotourism planning for protected areas. In Lindberg, K. \& Hawkins, D. (Ed.), Ecotourism: A guide for planners and managers (pp. 15-31). North Bennington, VT: The Ecotourism Society.

Boon, P. I., Fluker, M., \& Wilson, N. (2008). A ten-year study of the effectiveness of an educative programme in ensuring the ecological sustainability of recreational activities in the Brisbane Ranges National Park, South-eastern Australia. Journal of Sustainable Tourism, 16(6), 681-697. doi: 10.1080/09669580802397053 
Boonzaier, E. (1996). Local responses to conservation in the Richtersveld National Park, South Africa. Biodiversity and Conservation, 5, 307-314. doi: 10.1007/BF00051776

Bosch, C. A. (1971). Redwoods: A population model. Science, 172 (3981), 345 - 349. doi: 10.1126/science.172.3981.345

Brown, T. J., Ham, S. H., \& Hughes, M. (2010). Picking up litter: An application of theory-based communication to influence tourist behavior in protected areas. Journal of Sustainable Tourism, 18(7), 879-900. doi: 10.1080/09669581003721281

Bryan, W. L. (2008). Can responsible travel exist in a developed country? In Stronza, A., \& Durham, W.H. (Eds.), Ecotourism and conservation in the Americas (pp. 93-113). Cambridge, MA: CABI Publishing. doi: 10.1079/9781845934002.0093

Cater, E. (1997). Ecotourism: Dimensions of sustainability. RECOFTC Report, 15, 14-25.

Ceballos-Lascurain, H. (1987). The future of ecotourism. Mexico Journal, 1, 13-14.

Che, D. (2005). Developing ecotourism in first world, resource-dependent areas. Geoforum, 37, 212-226. doi: 10.1016/j.geoforum.2005.02.010

Cornell, J. B. (1979). Sharing nature with children: A parents' and teachers' natureawareness guidebook. Nevada City, CA: Ananda Publications. Retrieved from ERIC database. (ED198980)

Davies, B. (2003). The role of quantitative and qualitative research in industrial studies of tourism. International Journal of Tourism Research, 5(2), 97-111. doi: $10.1002 /$ jtr.425

Dennis-Parks, R. M. (2004). Healthy Forests Restoration Act-will it really protect homes and communities? Ecology LQ, 31, 639.

Dharmaratne, G. S., Sang, F.Y., \& Walling, L. J. (2000). Tourism potentials for financing protected areas. Annals of Tourism Research 27(3), 590-610. doi: 10.1016/S01607383(99)00109-7

Diamond, J. M. (1994). Ecological collapses of ancient civilizations: The golden age that never was. Bulletin of the American Academy of Arts and Sciences, 37-59. doi: $10.2307 / 3824451$

Doremus, J. (1999). Ecotourism as a rural community development strategy. Retrieved from http://www.humboldt.edu/ storage/rcnwc/pdf/doremus.pdf

Dubin, J. (2008). Educating ecotourists: Lessons from the field. In Stronza, A., \& Durham, W.H. (Eds.), Ecotourism and conservation in the Americas (pp. 141-152). Cambridge, MA: CABI Publishing. doi: 10.1079/9781845934002.0141 
Durham, W. H. (2008). Fishing for solutions: Ecotourism and conservation in the Galapagos National Park. In Stronza, A., \& Durham, W.H. (Eds.), Ecotourism and conservation in the Americas (pp. 66-85). Cambridge, MA: CABI Publishing. doi: 10.1079/9781845934002.0093

Eagles, P. F. (2002). Trends in park tourism: Economics, finance and management. Journal of Sustainable Tourism, 10(2), 132-153. doi: 10.1080/09669580208667158

Entwistle, A., \& Dunstone, N. (Eds.). (2000). Priorities for the conservation of mammalian diversity: Has the panda had its day? Cambridge, UK: Cambridge University Press.

Esterberg, K. G. (2002). Qualitative methods in social research. Boston, MA: McGrawHill.

Fennell, D. (1995). Ethics and ecotourism: A comprehensive ethical model. Journal of Applied Recreation Research, 20, 163-183.

Fennell, D. A. (1998). Ecotourism in Canada. Annals of Tourism Research, 25(1), 231235. doi: 10.1016/S0160-7383(97)00074-1

Fennell, D. (1999). Ecotourism: An introduction. New York, NY: Routledge.

Fennell, D. A., \& Dowling, R. K. (Eds.). (2003). Ecotourism policy and planning. Cambridge, MA: CABI Publishing. doi: 10.1079/9780851996097.0000

Fennell, D., \& Weaver, D. (2005). The Ecotourium concept and tourism-conservation symbiosis. Journal of Sustainable Tourism, 13(4), 373-390. doi: 10.1080/09669580508668563

California State Parks. (2005). The Forest of Nisene Marks State Park general plan. Retrieved from http://www.parks.ca.gov/pages/21299/files/tfonm-amendedgp-feir-88-05.pdf

Giannecchini, J. (2002). Ecotourism: New partners, new relationships. Conservation Biology, 7(2), 429-432. doi: 10.1046/j.1523-1739.1993.07020429.x

Giongo, F., Bosco-Nizeye, J., \& Wallace, G. N. (1994). A study of visitor management in the world's national parks and protected areas. North Bennington, VT: The Ecotourism Society.

Goodwin, H. (1996). In pursuit of ecotourism. Biodiversity and Conservation, 5, 277-291. doi: 10.1007/BF00051774 
Gossling, S. (1999). Ecotourism: A means to safeguard biodiversity and ecosystem functions? Ecological Economics, 29(2), 303-320. doi: 10.1016/S09218009(99)00012-9

Graham, F. (2011, November 18). Why close any state park? [Web log post]. Retrieved from http://franklincgraham.blogspot.com/2011/11/why-close-any-state-parkfranklin.html

Gubrium, J. F. (1997). The new language of qualitative method. New York, NY: Oxford University Press.

Hall, C., \& Weiler, B. (Eds.). (1992). Nature-based tourism, special interest tourism. London, UK: Belhaven Press.

Hall, C. M., \& Lew, A. A. (1998). Historical antecedents of sustainable development and ecotourism-new labels on old bottles? Sustainable Tourism: A Geographical Perspective, 13-24.

Ham, S. H., \& Weiler, B. (2003). Interpretation is persuasive when themes are compelling. Interpret Scotland, 8(3), 3-8.

He, G., Chen, X., Liu, W., Bearer, S., Zhou, S., Cheng, L. Y. (2008). Distribution of economic benefits from ecotourism: A case study of Wolong Nature Reserve for giant pandas in China. Environmental Management, 42, 1017-1025. doi: 10.1007/s00267008-9214-3

Home, R., Keller, C., Nagel, P., Bauer, N., \& Hunziker, M. (2009). Selection criteria for flagship species by conservation organizations. Environmental Conservation, 36(2), 139-148. doi: 10.1017/S0376892909990051

Irland, L. C. (1999). The northeast's changing forest. Petersham, MA: Harvard University Press.

Jacobson, S., \& Robles, R. (1992). Ecotourism, sustainable development, and conservation education: Development of a tour guide training program in Tortuguero, Costa Rica. Environmental Management, 16(6), 701-713. doi: 10.1007/BF02645660

Jamal, T., \& Hollinshead, K. (2001). Tourism and the forbidden zone: The underserved power of qualitative inquiry. Tourism Management, 22(1), 63-82. doi: 10.1016/S0261-5177(00)00020-0

Jones, J. (n.d.). Henry Cowell Redwoods State Park. California State Parks. Retrieved from http://www.parks.ca.gov/?page_id=916 
King, D. A., \& Stewart, W. P. (1996). Ecotourism and commodification: Protecting people and places. Conservation Biology 5(3), 293-305. doi: 10.1007/BF00051775

King, N., \& Horrocks, C. (2010). Interviews in qualitative research. Thousand Oaks, CA: Sage Publications Inc.

Koch, E. (1991). Rainbow Alliances: Community struggles around ecological problems. In Cock, J. and Koch, E. (Eds.), Going Green: People, Politics and the Environment in South Africa (pp. 15-16). Cape Town, South Africa: Oxford University Press.

Kruger, O. (2005). The role of ecotourism in conservation: Panacea or Pandora's box? Biodiversity and Conservation, 14, 579-600. doi: 10.1007/s10531-004-3917-4

Lepp, A. (2007). Residents' attitudes towards tourism in Bigodi village, Uganda. Tourism Management, 28, 876-885. doi: 10.1016/j.tourman.2006.03.004

Lindberg, K. (1991). Policies for maximizing nature tourism's ecological and economic benefits. Washington, DC: World Resources Institute.

Lindberg, K, \& Sproule, K.E.P. (1996). Ecotourism questioned: Case studies from Belize. Annals of Tourism Research, 23(3), 543-562. doi: 10.1016/0160-7383(95)00074-7

Mackinnon, J., Mackinnon, K., Child, G., \& Thorsell, J. (1986). Managing protected areas in the tropics. Gland, Switzerland: International Union for Conservation of Nature and Natural Resources.

The making of a state park. (n.d.). Wildways Illustrated. Retrieved from http://www.wildwaysillustrated.com/portfolio/portfolio_exhibits_img1.php

McCauley, D. J. (2006). Selling out on nature. Nature, 443, 27-28. doi: 10.1038/443027a

Mcgreevy, P., \& Megerian, C. (2012, July 20). California parks department finds \$54million surplus. Los Angeles Times. Retrieved from http://articles.latimes.com/2012/jul/20/local/la-me-state-parks-20120721

Menkhaus, S., \& Lober, D. J. (1996). International ecotourism and the valuation of tropical rainforests in Costa Rica. Journal of Environmental Management, 47(1), 1-10. doi: 10.1006/jema.1996.0031

Michaelidou, M., Decker, D., and Lassoie, J. (2002). The interdependence of ecosystem and community viability: A theoretical framework to guide research and application. Society and Natural Resources, 15, 599-616. doi: 10.1080/08941920290069218

Miles, J. C. (1991). Teaching in wilderness. The Journal of Environmental Education, 22(4), 5-9. doi: 10.1080/00958964.1991.9943055 
Miles, M. B., \& Huberman, A. M. (1984). Qualitative data analysis: A sourcebook of new methods. Beverly Hills, CA: Sage Publications Inc.

Noss, R.F. (2000). The Redwood forest: History, ecology, and conservation of the coast redwoods. Washington, DC: Island Press.

Orams, M. B. (1996). Using interpretation to manage nature-based tourism. Journal of Sustainable Tourism, 4(2), 81-94. doi: 10.1080/09669589608667260

Parker, S., \& Khare, A. (2006). Stakeholder engagement and environmental protection: A new framework for small ecotourism operators. International Journal of Environment, Workplace and Employment, 2(2), 206-225. doi:

10.1504/IJEWE.2006.011082

Pearce, A. B., \& Ocampo-Raeder, C. (2008). A Montana lodge and the case for defined ecotourism. In Stronza, A., \& Durham, W.H. (Eds.), Ecotourism and conservation in the Americas (pp. 114-128). Cambridge, MA: CABI Publishing. doi: $10.1079 / 9781845934002.0114$

Pickering, C., \& Ballantyne, M. (2012). Orchids: An example of charismatic megaflora tourism? In Holden, A., \& Fennell, D. A. (Eds.), The Routledge handbook of tourism and the environment (pp. 192-199). New York, NY: Routledge.

Pretes, M. (1995). Postmodern tourism: The Santa Claus industry. Annals of Tourism Research, 22(1), 1-15. doi: 10.1016/0160-7383(94)00026-O

Romeril, M. (1985). Tourism and the environment-towards a symbiotic relationship. International Journal of Environmental Studies, 25(4), 215-218. doi: 10.1080/00207238508710228

Ross, S., \& Wall, G. (1999). Ecotourism: Towards congruence between theory and practice. Tourism Management, 20(1), 123-132. doi: 10.1016/S0261-5177(98)000983

Ruschmann, D. M. (1992). Ecological tourism in Brazil. Tourism Management, 13(1), 125-128. doi: 10.1016/0261-5177(92)90048-C

Russell, W. H. (2000). Ecology and management of coast redwood (Sequoia Sempervirens) forests. Paper presented at the conference on the restoration and management of coast redwood forests: Jackson Demonstration State Forest. Fort Bragg, CA.

Russell, W. H. (2010). The influence of industrial forest management interests on forest restoration and carbon sequestration policy and practice. The International Journal of Environmental, Cultural, Economic and Social Sustainability, 6(5), 89-99. 
Ryan, C., \& Dewar, K. (1995). Evaluating the communication process between interpreter and visitor. Tourism Management, 16(4), 295-303. doi: 10.1016/02615177(95)00019-K

Salewski, V., Goken F., Korb J., \& Schmidt S. (2000). Has the white-necked rockfowl Picathartes Gymnocephala still a chance in Lamto, Ivory Coast? Bird Conservation International, 10, 41-46.

Sempervirens Fund. (n.d.). Our history and legacy. Retrieved from http://www.sempervirens.org/history.php

Shanahan, J., Pelstring, L., \& McComas, K. (1999). Using narratives to think about environmental attitude and behavior: An exploratory study. Society and Natural Resources, 12, 405-419. doi: 10.1080/089419299279506

Seidman, I. E. (1991). Interviewing as qualitative research: A guide for researchers in education and the social sciences. New York, NY: Teacher's College Press

Simberloff, D. (1998). Flagships, umbrellas, and keystones: Is single-species management passé in the landscape era? Biological Conservation, 83(3), 247-257. doi: 10.1016/S0006-3207(97)00081-5

Stephens, S. L., \& Fry, D. L. (2005). Fire history in coast redwood stands in the northeastern Santa Cruz Mountains, California. Fire Ecology, 1(1), 2-19. doi: 10.4996/fireecology.0101002

Stewart, W. (2007, March). The new economies of the redwood region in the 21st century. Paper presented at the Redwood Science Symposium. Mendocino, CA.

Strauss, A., \& Corbin, C. (1990). Grounded theory in practice. Thousand Oaks, CA: Sage Publications, Inc.

Sun, C. (2006). A roll call analysis of the Healthy Forests Restoration Act and constituent interests in fire policy. Forest Policy and Economics, 9(2), 126-138. doi:

10.1016/j.forpol.2005.03.011

Tisdell, C., \& Wilson, C. (2001). Wildlife-based tourism and increased support for nature conservation financially and otherwise: Evidence from sea turtle ecotourism at Mon Repos. Tourism Economics, 7(3), 233-249. doi: 10.5367/000000001101297847

Urias, D. (2009). International service-learning in ecotourism and empowerment of students and local communities. In Lin, J., \& Oxford, R. (Eds.). Transformative eco education for human and planetary survival (pp. 203-217). Washington, DC: Information Age Publishing. 
Valentine, P. (1991). Nature-based tourism: A review of prospects and problems. Proceedings of Congress on Coastal and Marine Tourism. Newport, Oregon: National Coastal Resources Research \& Development Institute.

Valetine, P. (1992). Review: nature-based tourism. In Weiler, B., \& Hall, C. M. (Eds.), Special interest tourism (pp. 105-127). London, UK: Belhaven Press.

Valentine, P. (1993). Ecotourism and nature conservation: A definition with some recent developments in Micronesia. Tourism Management, 14(2), 107-115. doi: 10.1016/0261-5177(93)90043-K

Verissimo, D., Fraser, I., Groombridge, J., Bristol, R., \& MacMillan, D. C. (2009). Birds as tourism flagship species: A case study of tropical islands. Animal Conservation, 12(6), 549-558. doi: 10.1111/j.1469-1795.2009.00282.x

Wearing, S., \& Neil, J. (1999). Ecotourism: Impacts, potentials and possibilities. Oxford, UK: Butterworth Heinemann.

Weaver, D. B., \& Lawton, L. J. (1999). Overnight ecotourist market segmentation in the Gold Coast hinterland of Australia. Journal of Travel Research, 40(3), 270-280. doi: $10.1177 / 0047287502040003005$

Weaver, D. B. (2001). Ecotourism in the context of other tourism types. In D. B. Weaver (Ed.), The encyclopedia of ecotourism (pp. 73-83). New York, NY: CABI Publishing. doi: 10.1079/9780851993683.0073

Weaver, D.B. (2005). Comprehensive and minimalist dimensions of ecotourism. Annals of Tourism Research 32(2), 439-455. doi: 10.1016/j.annals.2004.08.003

Weaver, D. B., \& Lawton, L. J. (2007). Twenty years on: The state of contemporary ecotourism research. Tourism Management, 28(5), 1168-1179. doi: 10.1016/j.tourman.2007.03.004

Wight, P. (1996). North American ecotourism markets: Motivations, preferences, and destinations. Journal of Travel Research, 35(1), 3-10. doi: $10.1177 / 004728759603500102$

Ziffer, K. A. (1989). Ecotourism: The uneasy alliance. Washington, DC: Conservation International 
Appendix A: Interview Protocol

1. Can you tell me how you came about working here?

2. What is your educational background?

3. Can you tell me a little bit about the history of the park(s)?

4. What is the role of the state parks in managing these parks?

5. Could you tell me a little bit about the management hierarchy?

6. Can you talk about the role of the state parks in delivering information to the public?

7. How does the state park system educate the public about conservation and protection of redwood forests?

8. Do you think redwood forests are at any environmental risk here? Why?

9. How do the state parks manage the forests? (Thinning, monitoring environmental, tourist impacts)

10. Is there a gap between the management policies and what happens in reality?

11. Can you describe the environmental policy and impacts?

12. How do you deal with these impacts?

13. Is there a working relationship with any part of the local community? 
14. Does climate change affect the forests? Could you please elaborate?

15. Does the "Healthy Forest Initiative" play a role in the forests' management? 


\section{Appendix B: Survey Questions}

The following questions are regarding your perceptions and ideas about ecotourism

and redwood forests. There are no correct or incorrect answers. For the purpose of this survey, ecotourism has 3 goals: conservation of biological and cultural diversity; the promotion of sustainable use of biodiversity, by generating income, jobs and business opportunities; and sharing the benefits of ecotourism with local communities and indigenous people, by obtaining their informed consent and full participation in planning and management.

1. Age: $\square<25 \square 25-35 \square 36-45 \square 46-55 \square$ Above 55 yrs

2. Are you from: $\square$ This County $\square$ CA $\square$ U.S.A $\square$ Other Country (specify)

3. Have you been to a redwood forest before? (Y/N)

4. If yes, how many times have you been to a redwood forest?

$\square<5$ times $\square 5$-10 times $\square>10$ times

5. How often do you visit redwood forests?

$\square$ Once a year $\square$ Twice a year $\square$ More than twice a year

6. Have you visited this redwood forest before? (Y/N)

7. If Yes, how many times have you visited this park? 
$\square<5$ times $\square 5$-10 times $\square>10$ times

8. What is the primary reason for your visit to a redwood forest? (Check all that apply)

$\square$ Recreation $\square$ Hiking $\square$ Spiritual $\square$ Other (specify)

9. Redwood forests are at risk from timber extraction and logging, threatening wildlife habitat.

$\square$ Strongly Agree $\square$ Agree $\square$ Neither agree nor disagree $\square$ Disagree $\square$ Strongly disagree

10. Ecotourism can help conserve redwood forests.

$\square$ Strongly Agree $\square$ Agree $\square$ Neither agree nor disagree $\square$ Disagree $\square$ Strongly disagree

11. How much would you be willing to pay to visit a redwood forest?

$\square<\$ 5 \square \$ 5-\$ 10 \square \$ 11-\$ 15 \square \$ 16-20 \square>\$ 20$

12. How much would you be willing to pay each year towards conservation of the forest?

$\square<\$ 5 \square$ \$5-\$10 $\square$ \$11-\$15 $\square$ \$16-20 $\square>\$ 20$ (specify) $\$$ 
13. How would you like your fee/donation to be spent/ allocated? (Check all that apply)

$\square$ Conservation of forest $\square$ Tourist facilities maintenance $\square$ Timber management/ harvesting $\square$ Other (specify)

14. What is your expectation when you go into a redwood forest? (Check all that apply)

$\square$ Tranquil environment $\square$ Lush forest $\square$ Big redwood trees $\square$ Multiple-use forest

$\square$ Shopping facilities $\square$ Other (specify)

15. What ideas, if any, do you have to conserve and protect redwood forests? 